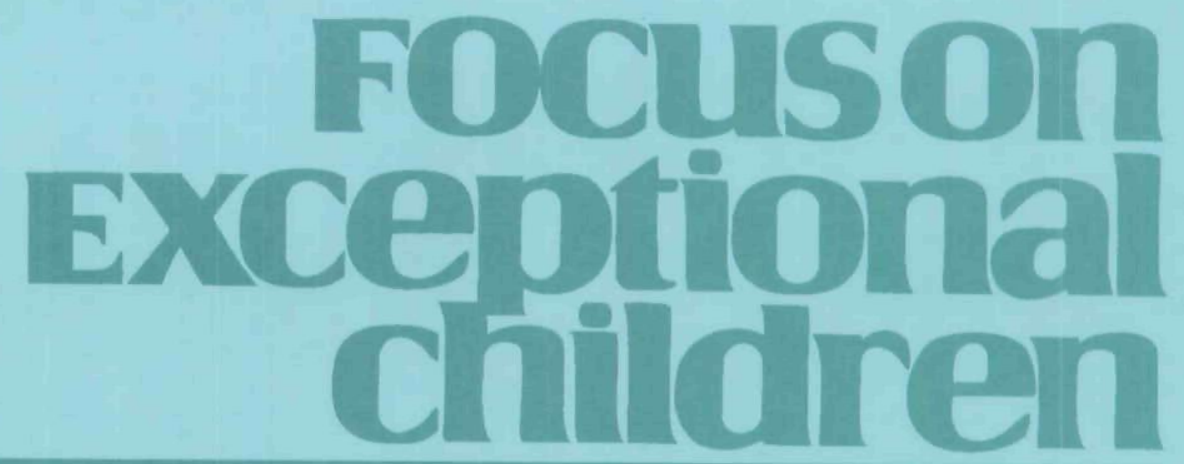

\title{
School Violence and Disruption Revisited: Equity and Safety in the School House
}

\author{
Matthew J. Mayer and Peter E. Leone
}

In the September, 2000, issue of Focus on Exceptional Children, we, along with several colleagues, examined school violence and related disorders through ecological and other perspectives (Leone, Mayer, Malmgren, \& Meisel, 2000). That article attempted to move beyond a discussion limited to child-centered characteristics and toward the contexts of children's lives. Our analysis of school violence examined family structure and poverty, exposure to violence in popular media, access to guns, and influences in the education system (e.g., accountability, zero tolerance) that might help to explain school violence and disorder. After presenting data on the extent of school violence and disorder, we closed with a discussion of promising approaches to preventing school violence.

Now, with the benefit of hindsight, we reexamine the issues raised in the 2000 Focus on Exceptional Children article and related developments in school violence reporting and prevention since that time. We begin with a review of current reports on school violence and related research. Next we revisit and update information on several key issues discussed in the original article, including (a) data collection and interpretation, (b) family structure and supervision of children, (c) poverty and income inequity, (d) exposure to violence in the media, (e) media coverage of school violence, (f) access to guns, (g) accountability and high-stakes testing, and (h) zero tolerance policies. We then revisit key areas of school violence prevention, legislative developments, the nexus of students' social skills, mental health, bullying, school exclusion, and tradeoffs between educational rights and maintaining a safe and orderly environment. The article concludes with suggestions for a balanced approach to prevention.

\section{TRENDS IN SCHOOL VIOLENCE}

Multiple indicators show a decline in school violence and disruption over the past decade. Several sources, however, indicate that significant problems continue, and that a new, lower plateau of school violence has been realized, suggesting that subsequent significant declines may not be forthcoming. For example, data from the CDC Youth Risk Behavior Survey (YRBS), as reported in Indicators of School Crime and Safety (ISCS) (DeVoe, Peter, Noonan, Snyder, \& Baum, 2005; Dinkes, Cataldi, Kena, \& Baum, 2006), show striking declines from 1993 to 2005 in the percentage of students in a fight at schools

Dr. Mayer is affiliated with Rutgers University, and Dr. Leone with the University of Maryland. 
and bringing a weapon to school (see Figure 1). But YRBS data for the same 10-year period show some stability in student reports of being threatened or injured with a weapon at school and missing school because of safety concerns (see Figure 2).

Several measures from the National Crime Victimization Survey (NCVS), also reported in the ISCS 2006, show a clear pattern of decline from 1993 to 2005 in rates of crime at and away from school (see Figure 3), including serious violent crime (rape, sexual assault, robbery, and aggravated assault), violent crime (serious violent crime and simple assault), and theft. In sum, school violence and disruption have declined significantly over the past 10 years, stabilizing somewhat at a lower level, but serious problems remain.

\section{MEASURING SCHOOL VIOLENCE}

Collecting and accurately reporting school violence data can be a daunting task. Information about school violence originates from many different sources, with some data reflecting criminal acts and other data on victimization.

\section{FOCuson
Exceptional
children}

ISSN 0015-511X FOCUS ON EXCEPTIONAL CHILDREN (USPS 203-360) is published monthly except June. July, and August as a service to teachers, special educators, curriculum specialists, administrators, and those concerned with the special education of exceptional children. This publication is annotated and indexed by the ERIC Clearinghouse on Handicapped and Gifted Children for publication in the monthly Current Index to Journals in Education (CIJE) and the quarterly index, Exceptional Children Education Resources (ECER). The full text of Focus on Exceptional Children is also available in the electronic versions of the Education Index. It is also available in microfilm from Serials Acquisitions, National Archive Publishing Company, P.O. Box 998. Ann Arbor, MI 48106-0998. Subscription rates: individual, \$42 per year; institutions, \$56 per year. Copyright (C) 2007. Love Publishing Company. All rights reserved. Reproduction in whole or part without written permission is prohibited. Printed in the United States of America. Periodical postage is paid at Denver, Colorado. POSTMASTER: Send address changes to:

Love Publishing Company

Executive and Editorial Office P.O. Box 22353

Denver, Colorado 80222

Telephone (303) 221-7333

\section{EDITORIAL BOARD}

\begin{abstract}
Lisa Dieker
University of Central Florida
\end{abstract}

Paula Maccini University of Maryland

Marleen Pugach

University of Wisconsin-Milwaukee

Carrie E. Watterson Editor
Stanley F. Love Publisher
Information is collected and reported by the FBI and other law enforcement agencies, schools and education agencies, and researchers. The FBI administers the Uniform Crime Reporting Program (UCR), which collects crime statistics from local and state agencies (Cook \& Laub, 1998). These data, however, can present inaccurate estimates of the extent of violent acts and number of perpetrators in a community. For example, arrest records often include individuals who are found to be innocent and also do not address behaviors that occur but are not observed and dealt with officially. Victimization self-reports from surveys are subject to a multitude of error sources, including inappropriate sampling frame, problematic instrumentation, and respondent errors such as poor recall, comprehension difficulties, and telescoping effects (Biemer, Groves, Lyberg, Mathiowetz, \& Sudman, 1991).

Even well-designed national-level surveys are prone to problems with biased response patterns. For example, Furlong, Sharkey, Bates, and Smith (2004) suggested that the CDC Youth Risk Behavior Surveillance Survey (YRBSS) was subject to bias as a result of extreme response sets of respondents. Furlong and Sharkey (2006) reported difficulties in drawing conclusions from some national survey data on weapon-carrying in schools, in part because the surveys were neither developed nor validated specifically for this purpose and could present an incomplete or distorted picture of student behaviors. Large-scale survey data collection efforts, such as the School Crime Supplement (SCS) to the National Crime Victimization Survey (NCVS), the YRBSS, and the Metropolitan Life Survey of the American Teacher, vary with the purpose and design of the study and instrumentation and thus yield information that may vary in terms of human subjects, definitional issues surrounding acts of violence, and time frames measured (Leone, Mayer, Malmgren, \& Meisel, 2000; Sharkey, Furlong, \& Yetter, 2006).

The UCR, NCVS, and National Center for Health Statistics (NCHS) data have been analyzed for their uniqueness in terms of: "(a) domain of events, (b) unit of count, (c) timing of counting, and (d) sources of discretion and error in recording and counting events" (Reiss \& Roth, 1993). Reiss and Roth noted that measured variables were derived from socially constructed variables that can change over time as a reflection of changing values in society. Those authors further commented that incidents can be characterized in terms of perpetrators or victims, situation, location, timing, and duplicative versus nonduplicative counts. Collectively, these attributes can lead to differing interpretations of data on community- and schoolbased violence. This is evidenced in our earlier graphic figures of trends in school violence, in which some indicators suggested a steep, steady decline and others portrayed less dramatic earlier declines followed by a plateau effect. 


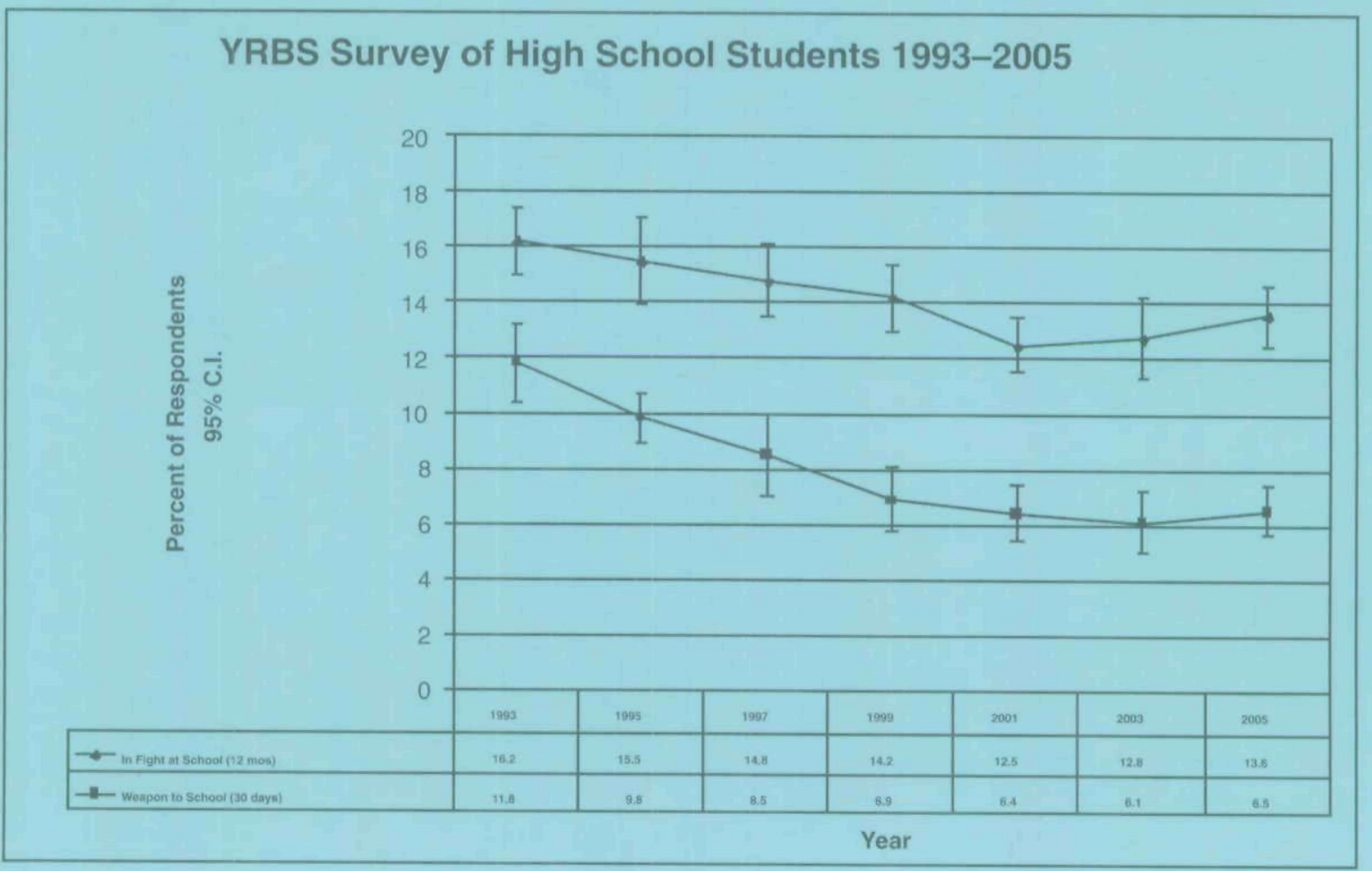

FIGURE 1

Fights at School; Weapons Brought to School

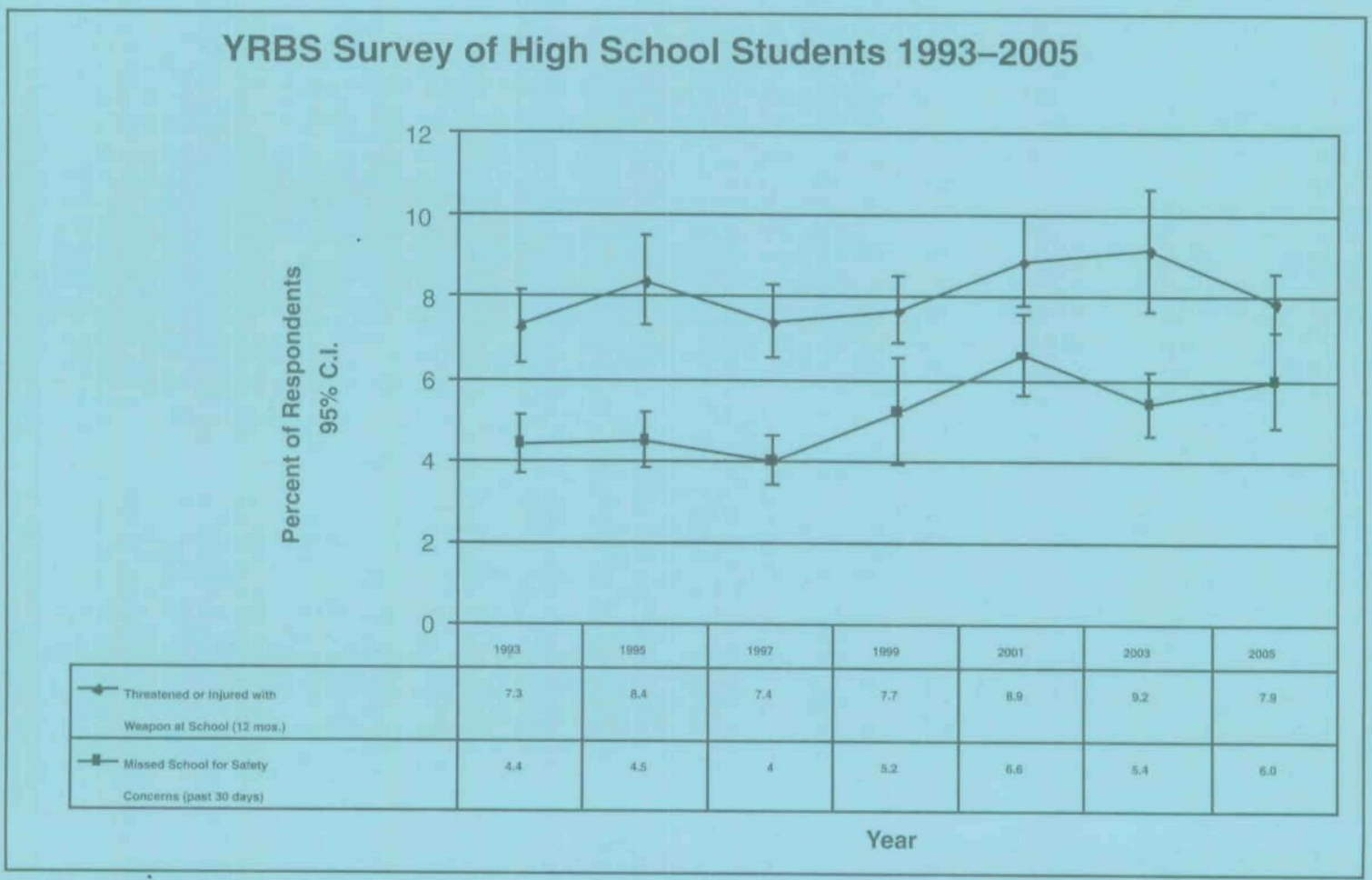

FIGURE 2

Threatened/Injured with Weapon; Missed School Because of Safety Concerns 


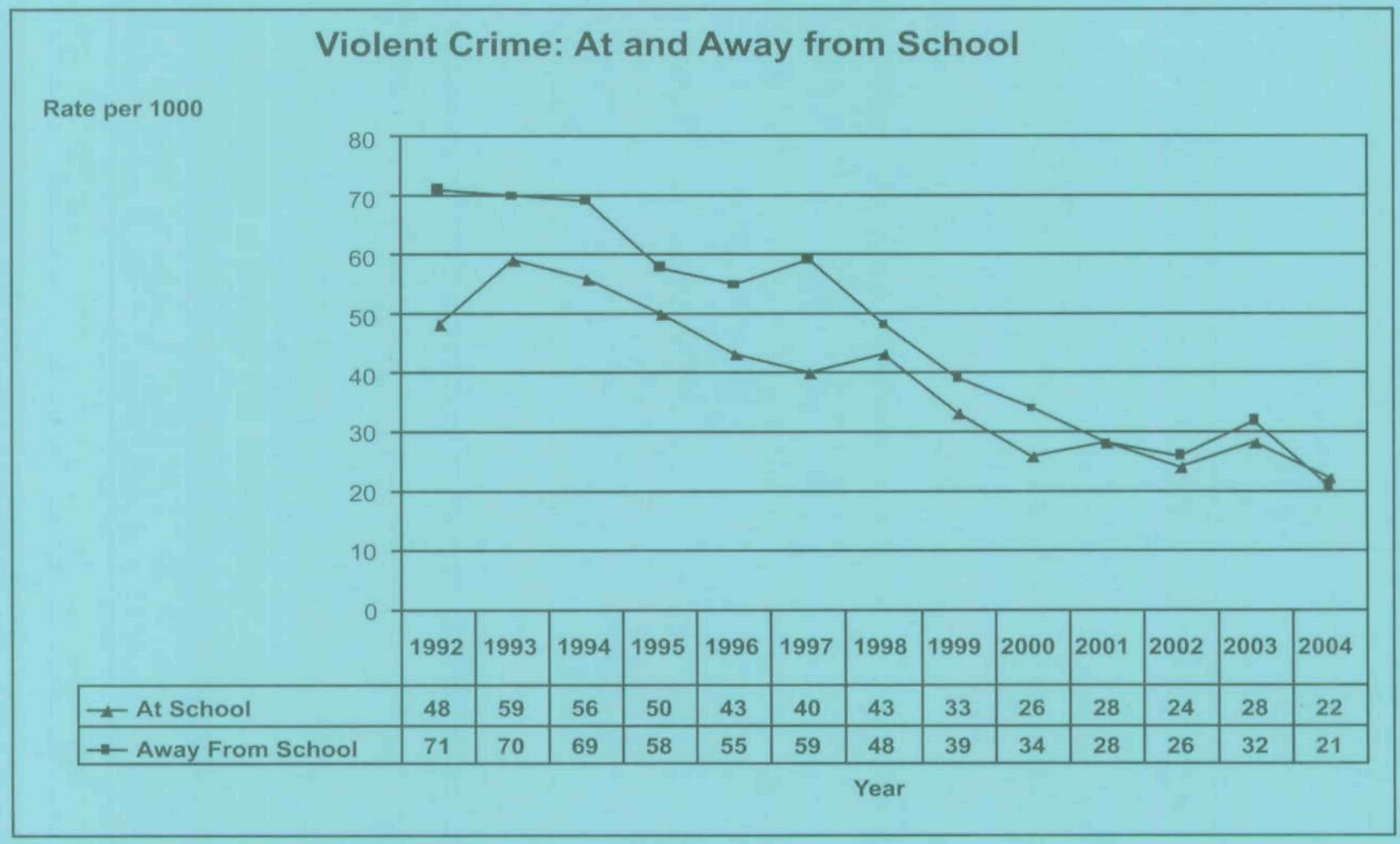

Source: National Crime Victimization Survey, reported in Indicators of School Crime and Safety 2006

Figure 3

Rate of Student-Reported Nonfatal Crimes Against Students Ages 12-18 per 1,000 students, by Type of Crime and Location

Although national surveys and assessments can present challenges for data collection and interpretation, locally produced data-collection devices such as self-report surveys are prone to reliability and validity problems, including inconsistencies in administrative implementation and instructions provided to student respondents (Cross \& Newman-Gonchar, 2004). Local- and state-level official educational record keeping on school violence and disorder lacks a uniform framework, which makes comparisons difficult. For example, some systems report student assault statistics based on unduplicated counts, and others use duplicated counts. Collecting data on the nature and prevalence of bullying in schools presents challenges because of varying definitions of bullying, different types of bullying, social contextual factors, cultural factors, and more general problems common to self-report measures (Cornell, Sheras, \& Cole, 2006).

On a local school level, the use of office referrals to study patterns of violence and disorder can be a problem (Morrison, Peterson, O'Farrell, \& Redding, 2004). For instance, a pattern of low office referral rates coupled with relative high suspension rates could signal a zero tolerance policy, or alternatively, selective use of office referrals for only serious problems. Likewise, variability in suspension data within states or school districts can lead to alternative interpretations of school-based problems (Morrison, Redding, Fisher, \& Peterson, 2006). Although data reporting in states having relatively few large school systems shows some consistency, states with hundreds of smaller local school districts are more prone to variability in data recording.

An audit in New York identified serious underreporting of school violence in many schools. Most schools from a sample of high schools audited did not report about onethird of serious violent and disruptive incidents; several schools did not report about $80 \%$ of violent incidents (Office of the New York State Comptroller, 2006).

\section{KEY ISSUES}

In the previous Focus on Exceptional Children article we linked our discussion of school violence to several ecological factors including family structure, supervision of children, 
poverty and income inequality, exposure to media violence, media coverage of school violence, access to guns, increased focus on academic accountability, and zero tolerance policies. These topics will be revisited here with an updated review of the literature.

\section{Family Structure and Supervision of Children}

Looking back 50 to 60 years, fewer than one-fifth of U.S. children lived in homes where both parents worked or were headed by a single parent. By the mid 1990 s, close to twothirds of children lived in households under these circumstances (Hernandez, 1995). In our 2000 Focus on Exceptional Children article the survey data suggested that from $4 \%$ to $23 \%$ of children were in self-care on a regular basis (Kerrebrock \& Lewit, 1999).

The Urban Institute (Vandivere, Tout, Zaslow, Calkins, \& Capizzano, 2003) found that overall, in 1999, 15\% of children ages 6-12 regularly did self-care, and about $7 \%$ of children ages $6-9$ and $26 \%$ of children ages $9-12$, cared for self after school. In comparison, data reported recently by the Federal Interagency Forum on Child and Family Statistics (2006) indicated that $22 \%$, or slightly more than one in five children in 4th through 8th grade in the United States, are caring for themselves regularly after school.

These data raise concerns about lack of after-school supervision when considering documented problems with violence and longer-term externalizing sequelae and their associated harmful effects to children resulting from early elementary grade experience in self-care, as well as unsupervised peer associations during later elementary years (Colwell, Meece, Pettit, Bates, \& Dodge, 2001; Elliott, Hamburg, \& Williams, 1998).

Older adolescents who did not live with both biological parents experienced significantly more problem behaviors than youth living with both parents (McCurley \& Snyder, in press). Specific behaviors included drug use and selling, gang involvement, running away from home, vandalism, and assault with intent to seriously injure. These findings partially mirror Lauritsen's (2003) analysis of National Crime Victimization data demonstrating that youth residing in higher-risk communities who were living with single parents were at greatly increased risk for being victims of violence, compared to youth living with both parents. A review of research in the National Research Council series Understanding and Preventing Violence further identified the following family risk factors significantly related to child and adolescent aggression and violence (Sampson \& Lauritsen, 1994):

- Parental neglect, including lack of supervision and lack of involvement

- Harsh punishment styles

- Marital discord

- Parental criminality

\section{Poverty and Income Inequity}

The number of children in families living in poverty in the United States has declined somewhat in recent years, from a high of $22 \%$ in 1993 to about $18 \%$ in 2004 (Annie E. Casey Foundation, 2004, 2006). Definitions and indicators of poverty, however, can present varying pictures, and key federal surveys of poverty have used slightly different methodologies (Bishaw \& Stern, 2006). For example, U.S. Census Department historical data on children younger than 6 years of age, under the heading, "Poverty Status of Related Children," reported $25.6 \%$ of children in poverty in 1993 and $19.8 \%$ in 2003.

Snyder and Sickmund (2006) reported that, in 2002, close to one-third of black juveniles lived in poverty and one-fifth of black children under age 5 lived in extreme poverty-less than $50 \%$ of the federal poverty threshold. Overall, the poverty rate for African American youth in 2004 was $36 \%$, compared to $11 \%$ for non-Hispanic white youth; and in 2004,33\% of single-parent families lived in poverty (Annie E. Casey Foundation, 2006).

Data from Wave-1 of the National Longitudinal Transitional Study-2 (NTLS-2) showed that for all 15- to 17-yearold students with disabilities in 2000-2001, approximately $29 \%$ were living in poverty, compared to more than $34 \%$ of students labeled as having emotional disturbance (ED) and about $16 \%$ of same-age youth in the general school population (Wagner, Cameto, \& Newman, 2003). Likewise, the U.S. Department of Education, Office of Special Education Programs (OSEP) Special Educational Elementary Longitudinal Study (SEEL) survey found that $24 \%$ of elementary students with disabilities and $31 \%$ of elementary students with emotional disturbance lived in poverty in 2000-2001 (Wagner, Marder, Blackorby, \& Cardoso, 2002).

While income inequality increased dramatically between 1968 and 1994, during the latter part of the 1990s and first few years of the millennia, it varied little in year-to-year reports. In a Census Department Press Briefing on 2004 poverty data, however, the Assistant Division Chief, Housing and Household Economic Statistics, remarked:

\footnotetext{
Over the last decade...the Gini index [a measure of income inequality] has increased, indicating a higher level of income inequality than in 1995. Also, the share of total income received by the highest $20 \%$ of households has increased while the shares received by those in lowest $60 \%$ have declined (emphasis added).
}

These remarks, along with the accompanying slides and data tables (U.S. Census Bureau, 2005) point to greater income inequality in the United States in recent years. Poverty has a significant effect on the adequacy and access to food and housing for many children.

The well documented harmful effects of poverty on children apply not only to those officially labeled as poor, 
according to federal poverty thresholds, but also to the nearpoor. Approximately $40 \%$ of children nationally in 2004 were living with families that could be considered poor or near-poor, in which "near-poor" is defined as under $200 \%$ of the federal poverty level (Association for Children of New Jersey, 2006).

When considering the poor and near-poor, it is instructive to examine data trends in housing and food security above and beyond consideration of income. "Food security" is defined as a family's ability to access sufficient food regularly to maintain a healthy, active lifestyle. Indicators of food insecurity include difficulty obtaining food, lesser quality of diet, anxiety about being able to get food, and use of emergency food sources (Federal Interagency Forum on Child and Family Statistics, 2005). In 2003, $18 \%$ of children were in households labeled "food-insecure." This presents a serious concern for the welfare of children and their healthy development, especially given knowledge of the deleterious effects of poor diet on cognitive development (Bryan et al., 2004; Donovan \& Cross, 2002; Pressley \& McCormick, 2007). Difficulties with sustainable, suitable, and safe housing can present problems for children with regard to physical safety, psychological well-being, and success in schoolacademically, socially, and behaviorally.

These problems, combined with other factors, can translate to later difficulties in externalizing and antisocial behaviors. In 2003, about $37 \%$ of homes (renters and owners) with children experienced some type of housing-related problem: financial problems in maintaining housing, overcrowding, or physically inadequate housing (Federal Interagency Forum on Child and Family Statistics, 2005). Households with children experiencing financial problems related to housing doubled between 1978 and 2003, increasing from $15 \%$ to $30 \%$. Overcrowded housing in homes with children decreased from $9 \%$ in 1978 to $6 \%$ in 2003.

\section{Exposure to Violence in the Media}

No credible academic debate remains as to the harmful effects on children of viewing violence on TV, in the movies, and through related media (American Academy of Pediatrics, 2001; American Psychological Association, 1993; Anderson \& Bushman, 2001; Anderson et al., 2003; Felson, 1996; Huesmann, Moise-Titus, Podolski, \& Eron, 2003; Reiss \& Roth, 1993; U.S. Department of Health and Human Services, 2001). "Short-term exposure increases the likelihood of physically and verbally aggressive behavior, aggressive thoughts, and aggressive emotions" (Anderson et al., 2003).

Huesmann et al. (2003) reported the results of a 15-year longitudinal study, which found that people across social strata are at increased risk for adult aggression and violence after having a steady high-level "diet" of violent television in childhood.
The Henry Kaiser Family Foundation (Rideout, Vandewater, \& Wartella, 2003) reported that about $47 \%$ of parents of children ages 4-6 indicated that their youngsters imitated aggressive behaviors they had seen on television, compared to $87 \%$ seeing their children imitate positive behaviors. Although the more widespread imitation of positive behavior models certainly is desired, having almost half of the respondents report imitation of aggression is a cause for serious concern.

Children spend a large proportion of their time watching television and are exposed to a great amount of media violence. Children in the United States average more than 6 hours per day of media involvement (American Academy of Pediatrics, 2001). Reviewing approximately 10,000 hours of television programs between 1995 and 1997, the National Television Study (Center for Communication and Social Policy, 1998) reported that more than $60 \%$ of the programming depicted interpersonal violence. Across all forms of popular media, images of serious violence occurred at an average rate of 14 times per hour, and for high violence shows, 54 times per hour (Lichter, Lichter, \& Amundson, 1999). By age 18, the average American child will have viewed on television more than 8,000 murders and 100,000 acts of violence.(Bushman \& Phillips, 2001). In an analysis of media and television violence, Derksen and Strasburger (1996) found six major effects of exposure to violence in the media:

1. Displacement of healthy activities

2. Modeling inappropriate behaviors

3. Disinhibition of socially proscribed behaviors

4. Desensitization to the harmful effects of violence

5. Aggressive arousal

6. Association with a constellation of risk-taking behaviors

\section{Media Coverage of School Violence}

Television and other media have maintained high-profile coverage of school shootings and other school tragedies throughout the 1990s and early 2000s (Arnette \& Walsleben, 1998; Brown, 2004; Reddy et al., 2001; Thompkins, 2000). Fortunately, what once seemed like an epidemic of school shootings and major school violence has diminished. Yet, media coverage of school violence has shaped the public's beliefs, and in many cases has led to a distorted perception of violence in schools, as well as adolescent violence more generally (Brooks, Schiraldi, \& Ziedenberg, 2000; Delizonna, Alan, \& Steiner, 2006; Gladden, 2002). A content analysis of six major newspapers found that reporting of urban versus rural school violence has been unbalanced in favor of reporting rural episodes (Menifield, Rose, Homa, \& Cunningham, 2001). 
A separate study of major newspaper and television reporting on five key children's issues (child abuse/neglect, child care, child health insurance, teen childbearing, and youth crime and violence) reported extremely disproportionate overcoverage of youth crime and violence; further, more than $90 \%$ of the reporting involved episodes or events rather than thematic stories that might provide context and better understanding of events (Kunkel, Smith, Suding, \& Biely, 2002). Fewer than 5\% of the stories on youth crime and violence included relevant contextual information on the topic.

Media accounts of crime and violence have been shown to affect public perception of events-especially in manipulating fear-and, in turn, affect public policy in response to those events (Altheide \& Michalowski, 1999; Haider-Markel \& Joslyn, 2001). The frequency of media reports of violence and terror consistently has been disproportionate to the actual frequency of such events (Gerbner, 1988; Marsh, 1991; Warr, 1994). Media accounts of school and community-based adolescent violence repeatedly have demonstrated factual errors in which a frenzy of coverage, with media-reporting-onmedia generation of second- and thirdhand accounts have distorted information much as an image is distorted from multiple photocopies of photocopies (National Research Council and Institute of Medicine, 2003). Children and adolescents are affected by this sort of news accounts (Cairns, 1990). Excessive and sometimes unbalanced reporting of school violence has led to copycat threats (Kostinsky, Bixler, \& Kettl, 2001).

Part of the problem can be linked to increasing consolidation of the news media since the early 1990s. Pursuant to the Telecommunications Act of 1996, more than $80 \%$ of television stations in the top 100 markets were groupowned, with emerging signs of increasing cross-ownership of television and newspapers (Howard, 1998). The 2006 Annual Report on the State of the News Media (Project for Excellence in Journalism, 2006) reported that journalistic propriety declined in favor of profits, and that about threefourths of Americans believe that major news organizations were more concerned with audience share than informing the public. The report also found that more news outlets were covering fewer stories, and with shrinking audiences, fewer news personnel were representing individual organizations. This led to more reporting-on-reporting, which can result in distortions of fact and less free access and more scripted control of the news as news staffers typically are herded together for briefings. In sum, evidence is emerging that consolidation in the media has led to a decline in objectivity and accuracy of news reporting, which in turn has affected reporting of school and youth violence-related incidents.

\section{Guns and Youth}

The United States has one of the highest rates of violent death for youth (ages 15-24) in the world (Butts et al., 2002). In 2003, in the United States, 4,567 children, adolescents, and young adults (ages $0-24$ ) were killed by firearms. Narrowing the focus, CDC WISQARS reporting system data indicate 2,849 firearm deaths for children and youth ages $0-19$ in 2003. Less than $1 \%$ of youth homicides are school-based, however (CDC, 2006). Data from the National School Safety Center Report on School-Associated Violent Deaths (2006) show that of the 425 school-based violent deaths from the 1992-93 school year through the 2005-06 school year, $74 \%$ (314) were shootings and 14\% (61) were stabbings or slashings. These statistics raise questions regarding overall levels of juvenile violence, access to weapons, particularly firearms, and related ecological risk factors.

Much of the research on gun-related juvenile violence has focused on prevalence of firearms in homes, the storage of firearms, and the relationships among availability of firearms, ecological risk factors, and violent behaviors. About one-third of U.S. households report owning guns (Cook \& Ludwig, 1997). With regard to school shootings, the vast majority of the firearms used by perpetrators came from the shooters' homes, or the homes of friends or relatives (Reza, et al., 2003).

Several studies have found that the probability of juveniles possessing guns increases significantly as a function of the local community (Blumstein \& Cork, 1996; Cook \& Ludwig; 2004). Stolzenberg and D'Alessio (2000) reported results of a study in South Carolina, using time-series analysis of data from the National Incident Based Reporting System (NIBRS) for 1991-1994. They found that the presence of an illegal gun market was a strong predictor of violent crime. Extending this finding, Braga and Kennedy (2001) demonstrated that juveniles access firearms through multiple illicit pathways, including unlicensed and corrupt dealers and individuals who illegally purchase guns for youth.

Using data from the 2001 CDC Youth Risk Behavior Survey (YRBS) from 38 states, as well as multiple data sources on firearms mortality and possible associated risk factors, Murnan, Dake, and Price (2004) analyzed the following variables for association with youth firearms deaths:

1. Child poverty rate

2. Percent of single-parent families

3. Percent of population that is African American

4. Percent of population that is Hispanic

5. Percent of students reporting carrying a gun

6. Percent of students reporting carrying a weapon

7. Percent of student reporting feeling unsafe

8. Percent of students reporting feeling sad/hopeless 
9. Percent of students at-risk academically

10. Percent of students involved in fighting

11. Percent of students involved in binge drinking

12. Violent crime rate for children and adolescents

13. Individual gun laws in each state

14. Prevalence of firearm ownership

15. Percent living in urban areas

They found that prevalence of firearm ownership was the single major predictor of child and adolescent deaths from firearms, responsible for $47 \%$ of the variance across states in child and adolescent deaths from firearms. In sum, multiple lines of research have demonstrated a clear connection between local availability of guns and gun-related violent behaviors.

Firearm storage practices and ecological risk factors have been linked to firearm-related deaths. A study of gun ownership and storage practices of a group of low-income urban families in the Pacific Northwest having at least one child in the 8-12 age range (Vacha \& McLaughlin, 2004) found that families living in fear of crime, in neighborhoods with high levels of crime, violence, drug use, and gang activity were much more likely to have guns at home and to keep them unlocked and loaded.

Okoro et al. (2005) reported on an analysis from the 2002 Behavioral Risk Factor Surveillance System (BRFSS), a data-collection effort by state health departments in coordination with the Centers for Disease Control and Prevention, utilizing data from approximately 223,000 respondents. About one-third of the respondents indicated that they have firearms at home. States showed significant variability in firearm possession as well as firearm storage practices. The study reported that an estimated 1.7 million children in the United States live in households with firearms stored loaded and unlocked. This finding parallels earlier findings (Schuster, Franke, Bastian, Sor, \& Halfon, 2000) of $35 \%$ of U.S. homes reporting gun ownership, with $13 \%$ of homes storing firearms where children-an estimated 2.6 million-had access.

Students repeatedly have indicated that they can obtain firearms fairly easily (Brown, 2004; Sheley \& Wright, 1998) and that they carry firearms for fear for self, to engender fear in others, to gain respect, or for self-protection. Of juvenile respondents (10th and 11 th graders), $48 \%$ indicated that they carried a firearm because of fear of neighborhood violence. In a study of suburban and rural youth (Cunningham, Henggeler, Limber, Melton, \& Nation, 2000), so-called high risk ownership of guns (to create fear, to get respect) was associated strongly with antisocial behavior. These youth were more likely than youth in low-risk and no-risk groups to engage in bullying behaviors. More than $14 \%$ of the 5 thto 7 th-grade students in this study owned rifles, and $9 \%$ owned pistols or handguns. Of those who owned handguns, $16 \%$ indicated that the reason for gun ownership was to earn respect or to frighten others, compared to $4 \%$ for youth owning BB or pellet guns, or rifles or shotguns. Brown (2004) reported additional differences between delinquent and nondelinquent juvenile in that delinquent juveniles were significantly more likely than non-delinquent juveniles to own and carry firearms.

In an analysis of responses to questions about weaponcarrying behaviors and experiences from about 1,600 students in 10 inner-city public high schools in four states from the North, South, East, and West, about 25\% of students reported carrying a weapon in school and four in 10 carried a weapon outside of school. Two-thirds personally knew another person who had been seriously assaulted at school (Sheley, McGee, \& Wright, 1995).

Trend data from the CDC Youth Risk Behavior Survey (YRBS) show that 9th-12th graders reporting that they carried a gun in the last 30 days declined from $7.9 \%$ in 1993 to $5.4 \%$ in 2005 , with variation during the latter years (1999-2005). Although the shorter period of 1993-1999 shows a significant decrease, there is no significant change when looking at the period 1999-2005. Looking at data from the Department of Justice Report Juvenile Offenders and Victims (Snyder \& Sickmund, 2006), firearm-related homicides by juveniles declined dramatically from 1994 to 2002 (see Figure 4).

Gun-related deaths and injuries of youngsters at school, as well in the community, remain a serious concern. Gun availability, along with community-based risk factors, has increased the likelihood of these horrific acts. Lax gun-storage practices in homes exacerbate the situation. A future reduction in these unnecessary deaths can be realized through coordinated efforts, including tighter controls on legitimate gun markets, cracking down on illegal gun distribution pipelines, educating adults about safe and secure gun storage practices, and intervening in schools and communities to reduce violence and alleviate fear of victimization.

\section{Accountability and High-Stakes Testing}

Subsequent to the critical report A Nation At Risk (National Commission on Excellence in Education, 1983), attention to high-stakes testing and accountability has increased. Students with disabilities had been excluded from statewide academic testing, but more recent legislation has changed things. For example, the 1997 IDEA Amendments required that students with disabilities be included in statewide and districtwide assessments. No Child Left Behind - the most recent reauthorization of the Elementary and Secondary Education Act (2002) - mandated testing of at least $95 \%$ of students, including four subgroups, of which one is students with disabilities. 


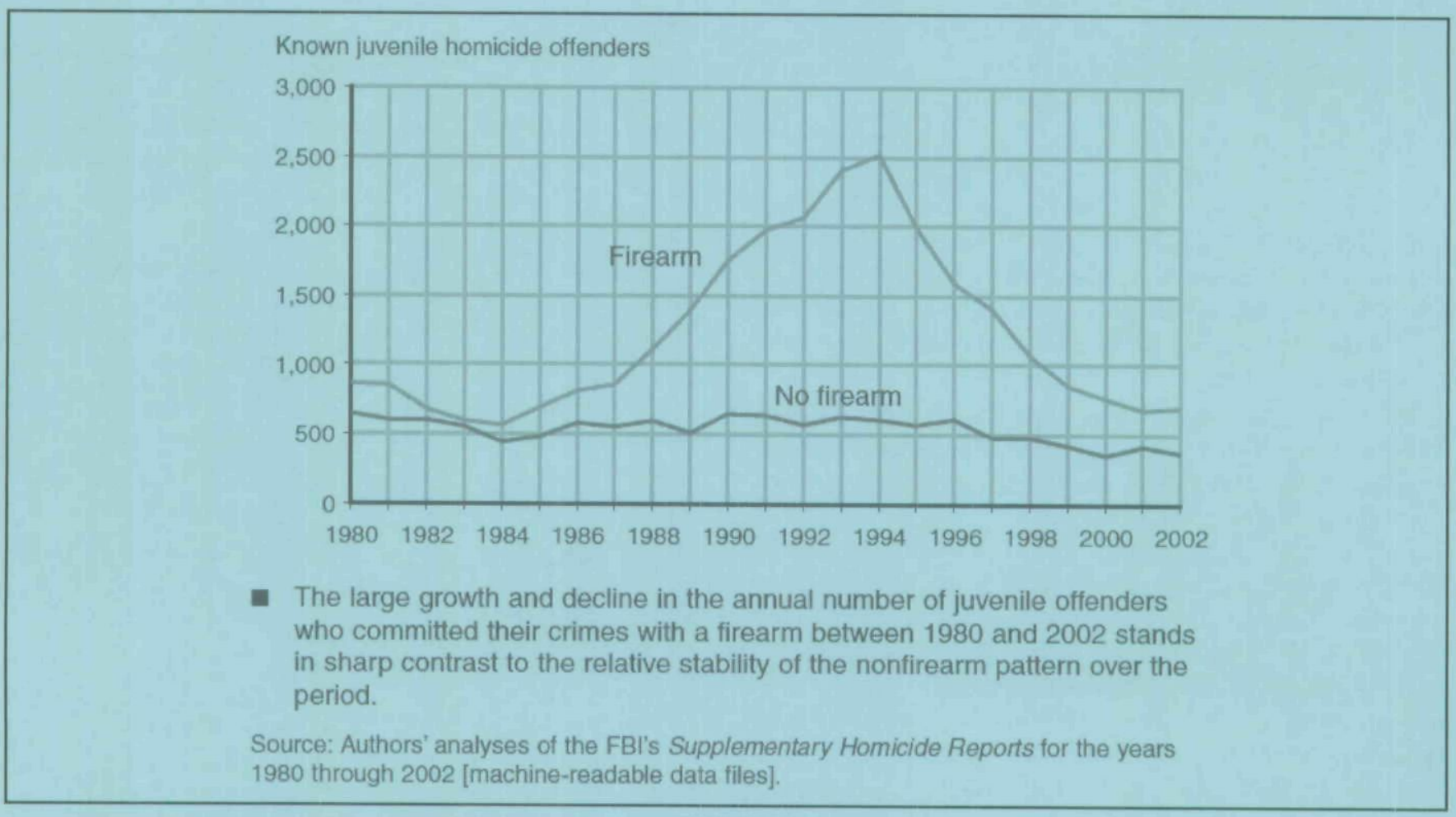

FIGURE 4 Juvenile Homicides with and without Firearms

Prior to the 1997 Amendments to IDEA and the 2002 enactment of No Child Left Behind, multiple initiatives at the state and national level addressed promotion and graduation testing-so-called high-stakes testing. High-stakes testing has raised concern among multiple education stakeholder groups because research on grade retention practices have been shown to lead to lower academic performance, self-esteem problems, and increased likelihood of dropping out (Heubert, 2002; Lehr, Johnson, Bremer, Cosio, \& Thompson, 2004; Nagaoka \& Roderick, 2004; Quenemoen et al., 2000; Reardon \& Galindo, 2002; Shepard, 1991).

As of the 2005-06 school year, 23 states had requirements in place for exit exam testing linked to earning a diploma (National Association of State Boards of Education, 2006). Even though more states have adopted graduation exams, youth of color and those with disabilities continue to graduate at lower rates then their peers. Approximately $50 \%$ of African American students graduated in 2001, as computed using Swanson's CPI method, and $51 \%$ of students with disabilities graduated as reported by OSEP (U.S. Department of Education, Office of Special Education Programs, 2006), compared to a national graduation rate of $68 \%$, per the CPI measure (Orfield, Losen, Wald, \& Swanson, 2004).

Emerging evidence indicates that state-level exit exams linked to graduation may be increasing the dropout rates.
Research also has suggested that students with disabilities and other at-risk students who may compromise a school's performance measures may be diverted from testing through "push-out" strategies and other indirect methods (Gotbaum, 2002; Heubert, 2002; Langenfeld, Thurlow, \& Scott, 1997; Shepard, 1991; Zweifler \& DeBeers, 2002). Several lines of research have established a link for at-risk students and students with disabilities, connecting school failure and dropping out to a poor employment history, relationship difficulties, and later criminal behaviors (Carson, Sitlington, \& Frank, 1995; Greenbaum et al.,1996; Hawkins, Farrington, \& Catalano, 1998; Hawkins et al., 1998; Wagner, 1995; Walker \& Sprague, 1999). An unintended consequence of the high-stakes testing and accountability movement may be the marginalization of at-risk students, including students of color and those with disabilities, exacerbating a trajectory that leads to later problems in life.

The poor fit of marginalized students remaining in school may be linked to disciplinary incidents involving violence and disruption. No data have been analyzed linking the onset of No Child Left Behind mandated high-stakes testing to changes in school violence and disruption, but visual inspection of multiple trend data show an association between the onset of NCLB testing and a leveling off of previous year-byyear declines in measures of school violence and disruption. 


\section{Zero Tolerance Policies}

Although there is no universally accepted definition of zero tolerance, in general it refers to policies and procedures that impose strict and inflexible punishments on rule-breakers, without consideration of personal, situational, or other contextual factors (American Bar Association, 2001; Skiba, 2000; Verdugo, 2002; Zweifler \& DeBeers, 2002). The zero tolerance movement is reported to have roots in the mid1980s drug-related personnel policies of the U.S. Navy, and the 1986 use of the term by a U.S. Attorney in California in reference to anti-drug trafficking initiative (Verdugo, 2002).

With an increased national focus on juvenile and school violence in the late 1980 s and early 1990 s, driven in part by media coverage of school-based incidents (Schiraldi \& Ziedenberg, 2001), schools across the country adopted socalled zero tolerance policies (Skiba \& Peterson, 1999). These policies originally were intended to address severe instances of violence, drug activity, and other behaviors considered severe or dangerous. Over the years, however, implementation of school-based zero tolerance has addressed, for the most part, a much wider variety of less serious behaviors (Beger, 2003; Casella, 2003; Gladden, 2002; Harvard University, Civil Rights Project, 2000; Skiba \& Peterson, 1999).

The most widely implemented sanction under zero tolerance is suspension from school, with expulsion used much less frequently (Harvard University, Civil Rights Project, 2000; Skiba, 2000). In 2000, just over 3,000,000 students were suspended nationally, and almost 100,000 were expelled from school (Snyder, Tan, \& Hoffman, 2006). Zero tolerance implementation is inconsistent across states, with serious excesses noted in Michigan, Kentucky, and other states (Michigan Nonprofit Association, 2003; Richart, Brooks, \& Soler, 2003; Zweifler \& DeBeers, 2002). Suspension from school has been found to have minimal effects on changing student behaviors (Gladden, 2002; Skiba, 2004), and in cases of multiple suspensions of a student, is strongly linked to an increased probability of dropping out (Harvard University, Civil Rights Project; U.S. Department of Education, National Center for Education Statistics, 2006).

Gladden (2002) comments that because zero tolerance does not address the causes of student misbehavior, individual and schoolwide problems continue unabated. A particularly insidious result of zero tolerance policies driving increased suspensions is the fueling of a downward spiral of school failure, disengagement from school, and increased association with peers demonstrating antisocial behaviorsan outcome also experienced by students with disabilities (ABA, 2001; Harvard Civil Rights Project; Gladden; Skiba, \& Peterson, 2000).

Zero tolerance policies have imposed hardship on students of color through highly disproportionate and often biased implementation (Harvard Civil Rights Project; Gladden; Skiba, 2000; Verdugo, 2002). Little data are available to support the effectiveness of zero tolerance policies, and not one in five national panels on school violence has supported zero tolerance as an efficacious intervention (Gladden, 2002; Skiba, 2000; Skiba \& Leone, 2001; Skiba \& Peterson, 1999; Verdugo, 2002).

Verdugo (2002) presents several compelling arguments relative to zero tolerance that involve cultural and structural factors in schools. Suggesting that zero tolerance policies deprive students of two guarantees of public education in the United States - the right to an education and equitable treatment-Verdugo points to the damage that these policies have done to the school-student bond. The cultural paradigm that Verdugo articulates has three dimensions:

1. Minority/poor students' rule-breaking behaviors are linked to both real and perceived structural barriers to life opportunities.

2. These understandings feed into an oppositional mindset relative to school.

3. The ensuing behaviors and reinforced mindset feed a vicious destructive cycle of failure. In essence, there is a cultural disconnect between schools and minority/ poor students, fostering an adversarial relationship.

The structural paradigm discussed by Verdugo (2002) also has three dimensions:

1. Isolation

2. School policies

3. School climate

Schools can isolate students of color and at-risk students through tracking and placement in special education, and indirectly through lack of encouragement and hostile relations. School policies that result in disproportionate discipline of minorities, as well as a lack of additional academic and social supports for high-risk students, do little to counteract the downward spiral of many at-risk students. Finally, negative school climate can be deleterious to positive social development, with incivility, intimidation, racial tensions, and harsh discipline reinforcing further disengagement from school.

In sum, zero tolerance has been shown to cause more harm than good. It is a source of racial discrimination in schools, pushing many at-risk students to drop out. It fosters a downward spiral of academic failure, disengagement from school, and antisocial behaviors. It has been applied inconsistently and abusively, causing unnecessary inconvenience and harm to students engaged in relatively minor behavioral transgressions. Zero tolerance does little to prevent school violence. 


\section{SCHOOL VIOLENCE PREVENTION}

Several reviews and meta-analyses of school-based violence-prevention programs were published between 2001 and 2006. A thorough review of secondary-level schoolbased interventions to reduce youth violence found that for youth identified as aggressive or at risk for aggression, interventions designed to lessen aggression, violence, bullying, conflict, or anger produced a standardized mean difference (a weighted effect size) of -0.41 (Mytton, DiGuiseppi, Gough, Taylor, \& Logan, 2006). The review included research using randomized controlled treatments, which included 56 studies. None of the studies included data on violent injuries.

An earlier meta-analysis by DiGuiseppi et al. (2002) found a standardized mean difference of -0.36 for schoolbased interventions designed to reduce aggression among students at risk for aggression. Farrington (2005) suggested that seemingly modest effect sizes should be considered more properly as larger when considered in terms of the percentage of persons diverted from problem behaviors. For example, given a weighted effect size of -0.36 , this result is approximately equal to reducing the percentage of controlgroup members engaging in aggression from $50 \%$ to about $32 \%$ - nontrivial change.

A meta-analysis of 165 studies of school-based interventions to reduce substance abuse, dropout, and conduct problems found varied results (Wilson, Gottfredson, \& Najaka, 2001). Four outcome measures were used: delinquent, criminal, and/or aggressive/violent acts; alcohol or other drug use; school dropout/disengagement; and antisocial/oppositional behaviors. Noncognitive-behavioral approaches resulted in negative outcomes and no demonstrable effectiveness. Cognitive-behavioral interventions and behavioral modification interventions that incorporated modeling and rehearsal showed modest positive effect sizes (e.g., 0.12 to 0.37 ) addressing all four outcome areas, and school disciplinary interventions were somewhat successful, especially in reducing delinquency outcomes.

Wilson, Lipsey, and Derzon (2003) analyzed 221 studies of school-based interventions to reduce aggression, in which the studies included outcome measures of aggressive behaviors. The interventions demonstrating the strongest effects were academic interventions, behavioral, and counseling programs. The analysis of demonstration programs and routine practice programs found an overall average effect size of 0.25 for the former, and 0.10 for the latter. The limited number of routine practices studies, however, severely limited the scope of the analysis and generalizability of those findings. Interventions that were teacher administered, were higher intensity, included one-on-one delivery, and showed high-quality implementation were associated most closely with the greatest reduction in aggressive behaviors.
Reviews of school violence-prevention interventions show promising effects for some interventions, and studies have been done in related areas such as appraisal of threat; environmental-, equipment-, and personnel-based security approaches; violence-prevention programming; schoolwide comprehensive programming; and methodological challenges in studying school violence and disorders (Bear, Giancola, Veach, \& Goetz, 2006; Furlong, Bates, Smith, \& Kingery, 2004; Furlong, Morrison, Skiba, \& Cornell, 2004; Jimerson \& Furlong, 2006; Skiba, Simmons, et al., 2004; Reddy-Randazzo et al., 2006). Although space limitations preclude a more extensive review in these areas, several themes emerge from a large body of recent literature.

\section{Threat Assesment}

Following what seemed like a nonstop occurrence of tragic school shootings in the mid- to late 1990 s, increased attention was devoted to developing methods of predicting - and thus preventing - future school tragedies. Efforts targeted assessment of individual level threats via profiling and other approaches, as well as broader schoolwide assessments of vulnerability to violence. For example, the U.S. Secret Service National Threat Assessment Center and the U.S. Department of Education engaged in collaborative research on threat assessment for school shootings (Vossekuil, Fein, Reddy, Borum, \& Modzeleski, 2002).

Three basic approaches to school violence assessment have included (a) profiling, (b) mental health assessments, and (c) automated decision processes (actuarial tools/expert systems/artificial intelligence). No evidence indicates, however, that any of these three student-focused approaches works (Reddy-Randazzo et al., 2006). Reddy-Randazzo et al. offered basic guidelines for a school-based threat assessment approach, and others have published more comprehensive treatment of the issue (Fein, Vossehuil, Pollack, Borum, Modzeleski, \& Reddy, 2002; Jimerson \& Brock, 2004; Cornell et al., 2004; Van Dyke, Ryan-Arredondo, Rakowitz, \& Torres, 2004).

In a related line of inquiry, Furlong, Bates, and Smith (2001) examined the statistical characteristics of profiling based on ROC [relative operating characteristic] curve analysis and found profiling to be ineffective, with a relatively large proportion of false positives. This suggests that, in the process of accurately targeting one potential school attacker, a dozen or more innocent students would be identified inappropriately (Furlong, Bates, \& Smith, 2001).

School violence researchers widely concur that profiling does not work. Cornell \& Williams (2006) reported on protocols for school-based threat assessment that do show promise, based on preliminary field test research involving 35 schools. That approach uses a systematic, decision tree 
process, in which trained teams gather and evaluate an array of threat-related data.

Taking a somewhat different perspective, Leone and Mayer (2004) articulated a view of school threat appraisal that did not focus on the individual student but, rather, at the school, from ecological, systemic, transactional, and relational perspectives. The authors identified disconnects in schools that fostered the following systemic risk factors:

- Academic missions that meshed poorly with students' needs

- Zero tolerance and primarily reactive, punitive approaches to school discipline

- Entrenched noncollaborative systems of control that isolated, rather than brought together, stakeholders

- Racial and cultural disconnects

- Disconnects with students with disabilities

Leone and Mayer posited the existence of an "unhealthy school syndrome" in which a confluence of these factors could set the stage for school violence and disorder.

\section{Managing the Physical Environment of the School}

During the same period of time, much attention has been directed to creating safer school premises, using environmental-, equipment-, and personnel-based measures. But effectiveness research on such school security measures is extremely limited. Sandia National Labs engaged in research on technology-based school security measures (Green, 1999), issuing a report, The Appropriate and Effective Use of Security Technologies in U.S. Schools. That document, however, did not include discussion of the research methodology, and it remains unclear how the authors arrived at the reported findings.

Research by Ginsberg and Loffredo (CDC, 1993) suggested that metal detectors could curtail the number of weapons brought into schools; however, there was no concurrent reduction in school violence and disorder at the classroom level. Other research suggested that school administrators and other school stakeholders may develop an unjustified sense of security resulting from the implementation of equipment-based measures designed to lower the incidence of school crimes (Ascher, 1994; Schneider, 2001). Drawing a slightly different picture, Wilson-Brewer and Spivak (1994) reported on a New York City school weapon-prevention approach that utilized school security staff with hand-held metal detectors. This approach led to a significant reduction in weapon-based incidents, with improved student attendance and indications that students felt safer at school.

Multiple research reports have suggested that using metal detectors, locking outside doors, searching lockers, and having hallway security patrols don't reduce classroom violence
(Aleem et al., 1993; CDC, 1993; Skiba \& Peterson, 2000; Gagnon \& Leone, 2001). Causal research demonstrating beneficial effects of these technologies is rare. Researchers have suggested that a near-exclusive focus on school security measures may alienate students, making schools seem like jails (Ascher, 1994; Brotherton, 1996; Juvonen, 2001; Mayer \& Leone, 1999; Noguerra, 1995; Peterson, Larson, \& Skiba, 2001).

\section{Personnel-Based Approaches: School Resource Officers (SROs)}

Compared to other research on school security, more work has been directed toward School Resource Officers (SRO) programs. One national study considered student interactions with SROs, student perceptions, and associations among environmental factors, neighborhood violence, student comfort in reporting crime, and students' feelings of safety (McDevitt \& Panniello, 2005). This study, however, did not investigate whether the presence of SROs is associated with lower rates of school violence.

Nine other studies, from North Carolina, Pennsylvania, Colorado, Kansas, New Hampshire, Virginia, and an unnamed southern U.S. city, offer some insights into the current state of knowledge (or lack thereof) regarding the effectiveness of SROs (Center for Schools and Communities, 2001; Chen, Chang, \& Tombs, 1999; Eisert, 2005a, 2005b; Foster \& Vizzard, 2000; Humphrey, 2001; Johnson, 1999; Klopovic, McDaniel, Sullivan, Vasu, \& Vasu, 1996; Virginia Department of Criminal Justice Services, 2000, 2001). Almost all of the studies employed mixed quantitative and qualitative methods, primarily using survey data. Only the Kansas study used moderately rigorous quantitative methodology. This body of research as a whole suggests that SROs are considered favorably by school personnel and parents, but while tending to be positive, have met equivocal responses from students. No study has demonstrated a causal link showing that SRO programs reduce school violence and disruption; however, the authors of many studies suggested that SROs help to reduce violence and disorder. More than half of the studies reported that students felt safer at school after the SRO program was established.

None of the studies mentioned has shown a causal relationship between specific security procedures and a reduction in school violence and disorder. Several investigations reported that metal detectors can reduce the number of weapons in schools, but several other studies have stated that metal detectors do not reduce school violence. No data have evaluated the effects of school security cameras in reducing violence or disruption. In summary, research has been lean and methodologically limited, and findings have been mixed. Among all the security approaches studied, 
SROs have seen the most favorable results, but even those findings must be evaluated with caution.

\section{Schoolwide Violence Prevention Programming}

Schoolwide violence prevention has taken multiple forms over the past decade, with approaches including (alone or in combination) (Gagnon \& Leone, 2001):

- systems-change such as Positive Behavior Supports,

- component programming that includes discrete evidence-based interventions, such as Second Step or Incredible Years,

- security and discipline-oriented approaches (discussed above), and

- multifaceted safe school programming, such as the Safe and Responsive Schools Program: A brief review of widely used prevention efforts follows.

Positive Behavioral Support (PBS) is a systemic approach that transforms the school environment to support overall student success, behaviorally, socially, and academically. PBS addresses schoolwide behavioral expectations, policies, and procedures that support positive student outcomes. The program is based on explicit instruction in desired behaviors, positive reinforcement, and data-driven decision making.

To deal with multiple levels of student need, PBS utilizes a multitiered intervention approach adapted from the public health model that includes primary, secondary, and tertiary intervention. A number of studies have demonstrated significant improvements in PBS schools as measured through fewer office referrals and disciplinary incidents, and improved academic outcomes (cf. Luiselli, Putnam, \& Sunderland, 2002; Nersesian, Todd, Lehmann, \& Watson, 2000; Nelson, Martella, \& Galand, 1998).

Schools often implement a variety of programming options, taking an a la carte approach. Some programs are mandated for all schools within a school district, and others are adopted within specific schools. These programming combination decisions can be driven in large part by local funding streams and special grants.

One of the more researched evidence-based programs in this category is Second Step, a multifaceted violence-prevention program that targets students in grades pre-K to 9th grade and their teachers, providing instruction in empathy, impulse control, problem solving, and anger management (Frey, Hirschstein, \& Guzzo, 2000). The Committee for Children - the organization that provides Second Step training - notes that schoolwide implementation of the program will offer superior results. As of 2006, approximately 27,000 U.S. schools were using the Second Step program.

The Safe and Responsive Schools (SRS) Program (Skiba, Ritter, Simmons, Peterson, \& Miller, 2006) exemplifies a comprehensive, preventive approach to schoolwide safe school programming. The SRS framework rests on three main components:

1. Creating a safe and responsive school climate that fosters a sense of belonging and caring, and teaches alternatives to violence, including conflict resolution and prosocial problem solving

2. Early identification and intervention for students atrisk academically and behaviorally, with referrals and provision of supports such as academic tutoring, mentoring, and anger management training

3. Effective responses to disruption and crisis including policies and procedures that address more serious disciplinary infractions and crises, but that use alternatives to suspension and expulsion that help maintain a more positive trajectory of student engagement and improvement

SRS is developed through a four-phase process:

1. Schoolwide team development

2. Needs assessment

3. Adoption of evidence-based practices

4. Associated strategic planning

Initial evaluation of SRS demonstrated relatively high levels of client acceptability and satisfaction, and evidence of significant reductions in school suspensions.

More recent research has focused on developing nextgeneration approaches to reducing school violence (Osher, Dwyer, \& Jimerson, 2006). The researchers synthesized prior research on school safety issues and identified eight conceptual areas of research that provide foundational knowledge of students learning and behavior:

1. Public health

2. Prevention/developmental science

3. Positive youth development (e.g., Social Emotional Learning, or SEL)

4. Behavioral research in special education (e.g., PBIS)

5. Mental health

6. Life course theory

7. Ecological theory

8. Transactional analysis

The authors stressed the overlap and alignment across many of these disciplines that help explain students' needs. Based on these conceptual frameworks, a comprehensive framework was developed with four core dimensions:

1. Connection with caring schools

2. Self-regulation and teaching SEL skills

3. Positive behavioral supports

4. Engaging and appropriate learning opportunities 
The researchers further provided a discussion of ways to address the diverse needs of students and guidelines for schools moving to implement such a framework. Similar multifaceted and comprehensive approaches are, for the most part, on the drawing board. They signal a critical shift in thinking and a likely direction for schools over the next decade.

\section{LEGISLATION, DISRUPTION, AND STUDENTS WITH DISABILITIES}

Nationally, legislation enacted or reauthorized during the past few years has addressed youth violence and antisocial behaviors in school and the community. In general, the legislative trends reflect a movement toward greater accountability for one's actions, a more punitive approach to discipline, treatment of students with disabilities in a manner more similar to the general student population, and overall, less tolerance for behaviors considered dangerous or disruptive.

\section{Gun-Free Schools Act}

The Gun-Free Schools Act (GFSA) (1994) grew out of national concern for escalating school violence, especially school shootings, use of firearms in and near schools, and access to firearms by school-age youth (Gladden, 2002; Mercy \& Rosenberg, 1998, Skiba, 2000). An earlier incarnation - the Gun-Free School Zones Act of 1990 - was nullified in U.S. v. Lopez (1995), when the Supreme Court declared it unconstitutional (Safra, 2000).

More recently, the GFSA was amended by the No Child Left Behind Act (PL 107-110) and includes language to make it consistent with IDEA. The GFSA mandates that each state receiving federal funding under the Elementary and Secondary Education Act provide legislation forcing local education agencies (LEAs) to expel students who bring a firearm to school. Under these state laws, LEA chief administrators can modify expulsions on a case-by-case basis.

The report to Congress on implementation of GFSA for the 2002-03 school year (USDOE Office of Safe and DrugFree Schools, 2006) found that, nationally, 2,143 students were expelled under GFSA, with $58 \%$ of the expulsions in high schools, $31 \%$ in junior highs, and $11 \%$ in elementary schools. This represented a $16 \%$ overall decrease from the previous year and is part of a dramatic pattern of decline since the 1996-97 school year, when 4,787 students were expelled under the law.

Interestingly, the 1996-97 figure of 4,787 represents a downward revision from a prior report of 6,093 expulsions (U.S. Department of Education, 1998), in which some states and outlying areas reported expulsions for weapons other than firearms. Of those expelled during the 2002-03 school year, $47 \%$ of the cases were modified. Students with disabilities accounted for $19 \%$ of the total number of students expelled. This is about $50 \%$ of the figure for the 1996-97 school year, during which students with disabilities represented $37 \%$ of those expelled.

\section{NCLB Unsafe School Choice Option: Persistently Dangerous Schools}

The enactment of No Child Left Behind (NCLB) legislation in January, 2002, introduced many new requirements for states to demonstrate accountability for student and school progress in multiple domains. A relatively minor provision of the legislation, the Unsafe School Choice Option ( $\$ 9532)$, introduced the concept of a "persistently dangerous school" (PDS). The Unsafe School Choice Option (USCO) requires each state to craft a definition of a PDS and offer students in schools so designated the choice to transfer to another "safe" school.

During the 2003-04 school year, 52 schools nationally were labeled persistently dangerous (Snell, 2005) with 44 of 50 states reporting no schools meeting requirements for the persistently dangerous category. These statistics are at odds with a large body of data demonstrating reduced, yet continuing school violence problems nationally. The U.S. House of Representatives Committee on Education and the Workforce held a field hearing on September 29, 2003, in Denver, Colorado, addressing implementation of the NCLB Persistently Dangerous Schools Provision (United States, 2004).

Multiple participants testified as to the problems with the unrealistic definitions that most states are using to determine PDS determination, with one witness pointing to the "fact" that the major cities of Los Angeles, Chicago, Miami, Detroit, Cleveland, San Diego, Baltimore, and Washington, DC, had no persistently dangerous schools. The net effect of the Unsafe School Choice Option of NCLB has been to drive state education agencies and their local school districts "into the closet," out of fear of NCLB sanctions, with regard to officially addressing persistently dangerous schools.

\section{Revisions to IDEA 2004 on Discipline}

The 2004 reauthorization of IDEA included several changes with regard to discipline and students with disabilities. In sum, the changes reflect a movement to bring disciplinary treatment of students served under IDEA closer to that of the general student population while also addressing public concerns about a system of dual disciplinary standards. The major disciplinary requirements included in the reauthorization of IDEA 2004 are summarized in the accompanying box. 


\section{SOCIAL SKILLS, MENTAL HEALTH, BULLYING, AND SCHOOL EXCLUSION}

What are the challenging behaviors of students with disabilities in schools? To help answer this question, we turn to several sources, including Special Educational Elementary Longitudinal Study (SEELS) data from the Office of Special Education Programs (OSEP), the National Longitudinal Transitional Study-2, and National Center for Educational Statistics data.

In our previous Focus article, we asked how often students with disabilities are involved in school violence and disruption. We do not have data to answer such a question directly, but we can carefully draw some inferences based on reports of suspension and expulsions, as well as related behavioral data. We examined Gun-Free Schools Act data and analyses of suspensions and expulsions from several states. At that time, we concluded that close to $20 \%$ of students with disabilities were suspended from school, that most behaviors for which students with disabilities were suspended were nonviolent, and that the nature of behaviors for which students with disabilities were suspended was substantively the same as nondisabled peers. Interestingly, recent NTLS Wave-1 data reports that more than $19 \%$ of students with disabilities were suspended from school during the 2001-02 school year with somewhat fewer the following year.

Other data paint a compelling picture of behaviors of students with disabilities. A SEELS parent survey (26th Annual

\section{IDEA 2004: A SUMMARY OF DISCIPLINARY REQUIREMENTS}

- A school district may remove a student who violates a student code of conduct from his or her current placement to an Interim Alternative Educational Setting (IAES), another setting, or suspend him or her for not more than 10 school days to the extent that similar procedures would be used with a student who did not have a disability.

- If a school district wants to order a disciplinary change of placement that exceeds 10 school days, the district must conduct a manifestation determination.

- When conducting a manifestation determination, the misbehavior can be determined to be a manifestation of a student's disability only if:

- the conduct in question was "caused by" the disability, or

- had a "direct and substantial relationship" to the disability, or

- if a school failed to implement a student's IEP as written.

- If a student's misbehavior was not a manifestation of his or her disability, the school may use disciplinary procedures that are used with students who do not have a disability. These procedures also may be used for the same duration of time although educational services must continue for any period beyond 10 school days.

- A student with a disability who is removed from his or her current placement in excess of 10 school days must continue to receive educational services that enable him or her to progress toward IEP goals and continue to participate in the general education curriculum. In addition, a functional behavioral assessment must be conducted as appropriate and the student must continue to receive behavioral interventions and supports.

- Students can be moved to an IAES if they possess or use weapons or drugs in school or at a school function or if they inflict serious bodily injury on another person while at school or a school function, without regard to whether the behavior was a manifestation of the student's disability.

- Students can be placed in an IAES for up to 45 school days (this is longer than the previously allowed 45 calendar days).

- The parent or Local Educational Agency (LEA) may appeal a decision on IAES placement. The hearing must occur within 20 days of the request, with a decision within 10 days following hearing.

- The stay-put placement during hearings in which a disciplinary sanction is challenged will be the IAES, not the setting the student was in before the dispute.

- Children or youth who currently are not in special education can receive protections under the disciplinary provisions of the IDEA if:

- the child's parents expressed their concern that their child needed special education services, in writing, to an administrator, supervisor, or teacher, or

- the child's teacher or other school personnel expressed concerns about the child's behavior directly to the special education director or other supervisory personnel. 
Report to Congress, 2006) shows that for students with disabilities in language arts instruction in 2001, parents reported that $17.9 \%$ of special education students had ever been suspended or expelled, compared to $8 \%$ of general education students. As indicated earlier, under the Gun Free Schools Act, students with disabilities accounted for $19 \%$ of students expelled during the 2002-03 school year, a sharp drop from $37 \%$ of the cases for the 1996-97 school year.

OSEP data drawn from SEELS and NLTS-2 reports social skill ratings of the general student population, compared to students with disabilities and, in particular, students coded ED (Bradley, 2003). Students with disabilities and the general student population showed significant differences in assertion and self-control skills. The students with disabilities, especially those with ED, fared substantially worse.
Within the group of students with disabilities, students with ED have more difficulty with cooperation skills and social skills overall compared to other students with disabilities.

We can also consider data showing parents' reports of student involvement in bullying and fighting at school (see Figure 5). Here we see striking differences between the general school population and students with disabilities, especially those labeled ED. As a whole, these data suggest an elevated risk for problem interactions in school (e.g., verbal disruptions, fights) that would lead to students with disabilities being suspended at disproportionately high rates.

Additional data from OSEP show noteworthy patterns in suspension/expulsion patterns (see Figure 6). We can note that, for elementary/middle school students, about $86 \%-$ $87 \%$ of general education students, as well as students with

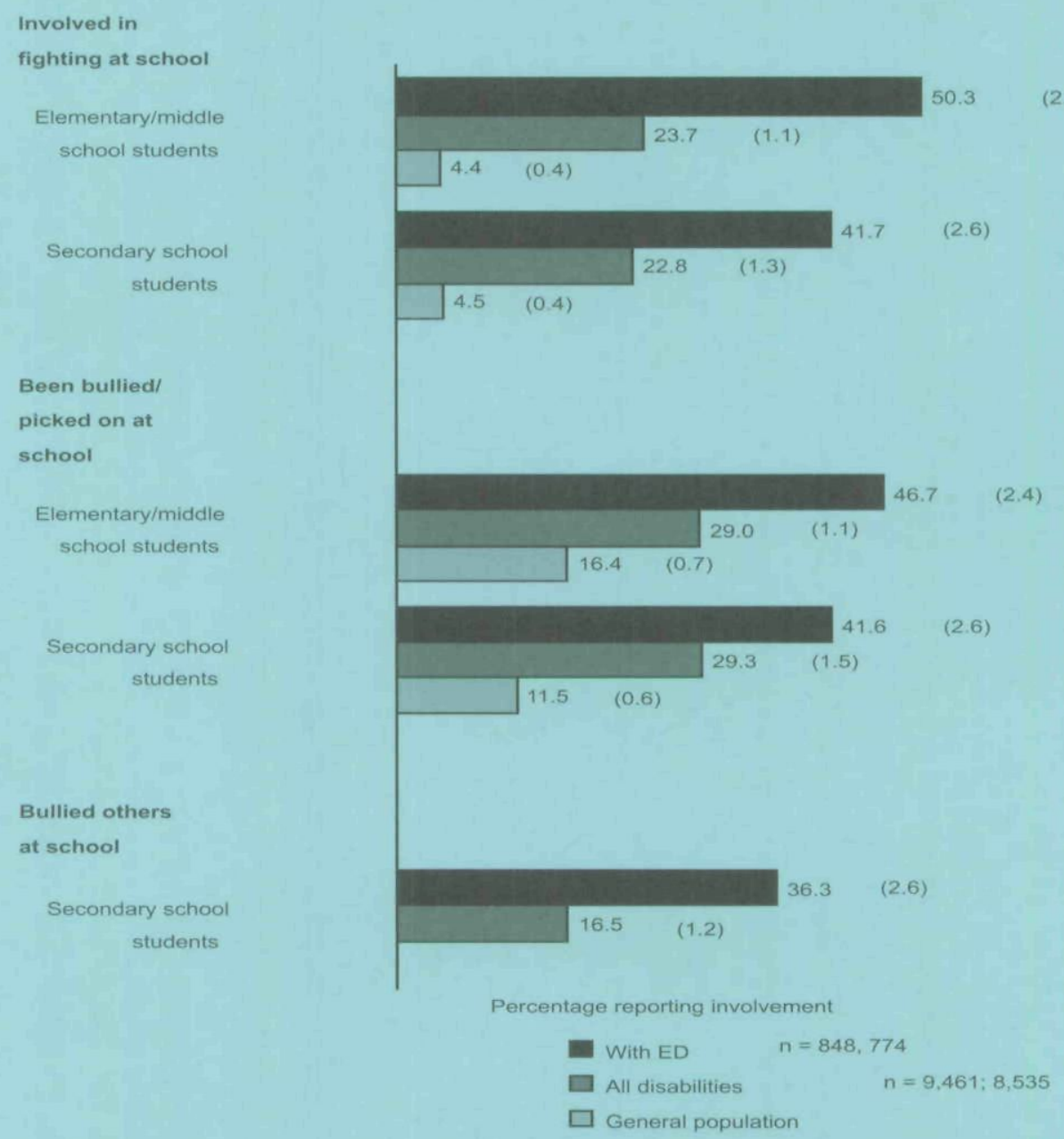

Source: Students with Emotional/Behavioral Disabilities: Data from OSEP's National Studies, by R. Bradley. Paper presented at Council for Children with Behavioral Disorders Annual Conference, St. Louis, MO, October 2003. 
disabilities overall, were neither suspended nor expelled. This stands in sharp contrast to only $51 \%$ of students with ED. At the secondary level, we note that $78 \%$ of the general student population and $67 \%$ of students with disabilities overall were neither suspended nor expelled. Within the population of students with disabilities at the secondary level, however, more than double the percent of students with ED were suspended, compared to students with disabilities overall ( $58.2 \%$ versus $25.6 \%$, respectively).

A statewide study of suspensions of students in Maryland revealed that African American youth and students with disabilities were more than two to three times as likely to be suspended than white students without disabilities (Krezmien, Leone, \& Achilles, 2006). Students identified as having emotional or behavioral disorders and other health impairments (including those with ADHD) and those with learning disabilities were at greater risk for suspension than their same-race peers
These data suggest continuing behavioral difficulties at school for students with disabilities, particularly those with emotional disturbance. As a group, students with disabilities are at elevated risk for suspension and expulsion. Focused prevention programs that attend to identified risk factors, such as limited self-control and social skills, are especially needed for this group. Although extant data do not shed light on the extent to which students with disabilities engage in more acts of school disruption or violence, and thus are more likely to be suspended, available information indicates that they are at much greater risk than other students for being excluded for disciplinary reasons.

Students with disabilities, especially those with ED, as well as others in the general education population, have significant mental health needs. Close to $20 \%$ of students have mental health disorders requiring some type of formal service support. About $70 \%-80 \%$ of youth's mental health services have been delivered through schools, but only about

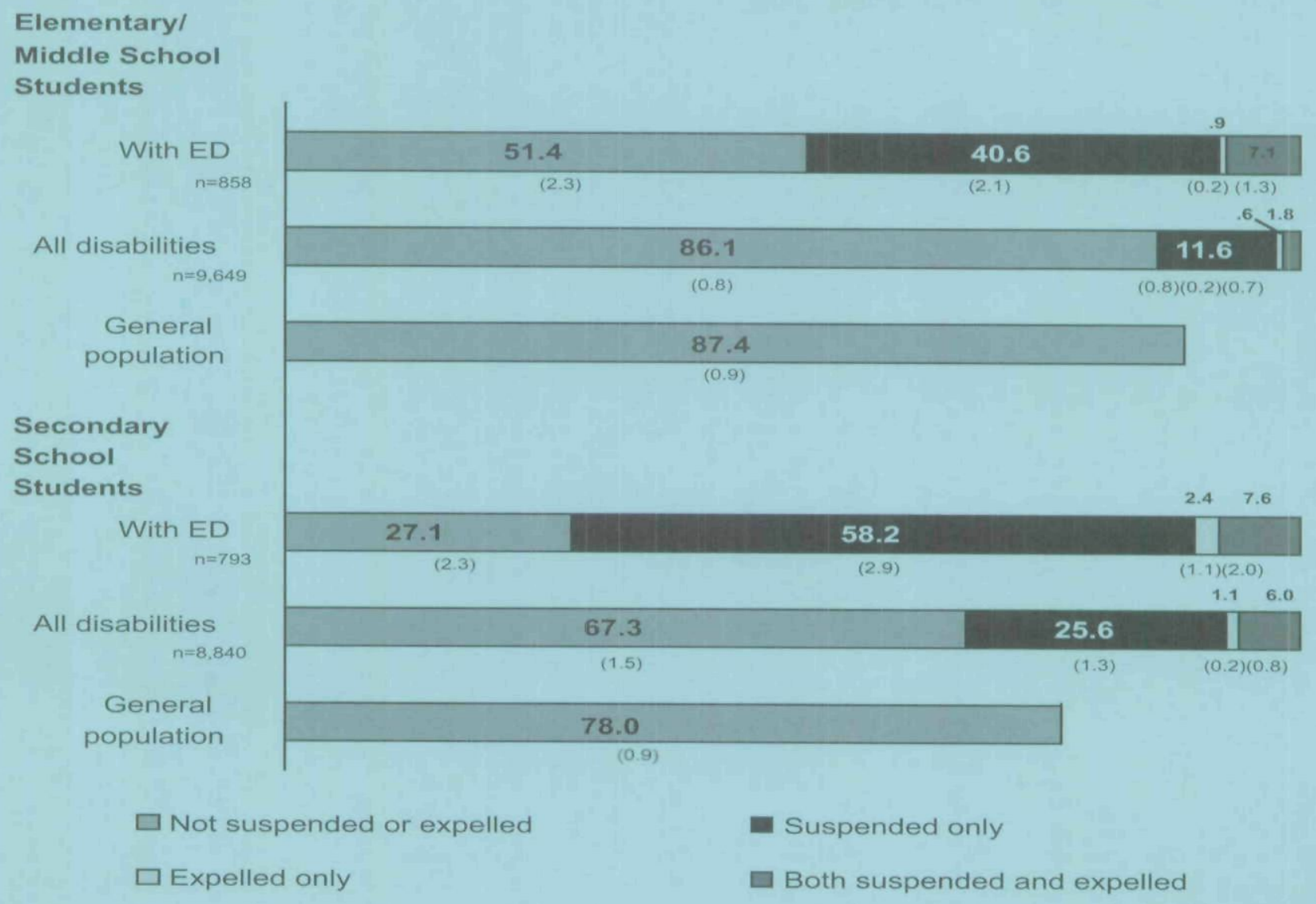

Source: Students with Emotional/Behavioral Disabilities: Data from OSEP's National Studies, by R. Bradley. Paper presented at Council for Children with Behavioral Disorders Annual Conference, St. Louis, MO, October 2003. 
$20 \%$ of students with the most severe mental health needs have received commensurate services (Hoagwood \& Johnson, 2003).

Data from the National Longitudinal Transition Study-2 (NLTS-2) and Special Education Elementary Longitudinal Study (SEELS) indicate that in 2001, approximately $70 \%$ of students with emotional disturbance (ED) received mental health services from somewhere, with about $40 \%$ of those services received in schools (see Table 1).

During 2001, approximately $14 \%-15 \%$ of students with disabilities received mental health service in schools. In 2005 those figures dropped to about $12 \%$ for elementary students, and $9 \%$ for secondary students. Parent reports of mental health services provided to their children, based on SEELS and NLTS-2 datasets, demonstrate a marked, statistically significant decline in school-based mental health services to students with ED between 2001 and 2005, from about $43 \%$ to $34 \%$ for elementary students, and $36 \%$ to $22 \%$ for secondary students with ED.

Likewise, overall availability of mental health services

TABLE 1

Mental Health Services in School and Elsewhere Provided to Students with Disabilities

\begin{tabular}{|c|c|c|c|c|c|}
\hline \multicolumn{2}{|c|}{ Students with ED (Emotional Disturbance) } & Wave 1 & Wave 3 & 2001-2005 & ${ }^{*}$ Sig \\
\hline \multirow[t]{2}{*}{ ELEMENTARY (SEELS) } & $\begin{array}{l}\text { MH from School } \\
\text { (S.E.) }\end{array}$ & $\begin{array}{c}0.435 \\
(0.025)\end{array}$ & $\begin{array}{l}0.338 \\
(0.03)\end{array}$ & 0.0065 & 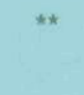 \\
\hline & $\begin{array}{c}\text { MH Anywhere } \\
\text { (S.E.) }\end{array}$ & $\begin{array}{r}0.709 \\
(0.0229)\end{array}$ & $\begin{array}{c}0.585 \\
(0.0312)\end{array}$ & 0.0007 & $\star \star \star \star$ \\
\hline \multirow[t]{2}{*}{ SECONDARY (NLTS2) } & $\begin{array}{c}\text { MH from School } \\
\text { (S.E.) }\end{array}$ & $\begin{array}{c}0.363 \\
(0.025)\end{array}$ & $\begin{array}{r}0.223 \\
(0.0607)\end{array}$ & 0.0165 & * \\
\hline & $\begin{array}{c}\text { MH Anywhere } \\
\text { (S.E.) }\end{array}$ & $\begin{array}{c}0.689 \\
(0.024)\end{array}$ & $\begin{array}{c}0.511 \\
(0.0729)\end{array}$ & 0.0102 & $\star \star \star$ \\
\hline \multicolumn{2}{|c|}{ Students with Disability } & $\begin{array}{c}\text { Wave } 1 \\
2001\end{array}$ & $\begin{array}{c}\text { Wave } 3 \\
2005\end{array}$ & & \\
\hline \multirow[t]{2}{*}{ ELEMENTARY (SEELS) } & $\begin{array}{c}\text { MH from School } \\
\text { (S.E.) }\end{array}$ & $\begin{array}{r}0.141 \\
(0.0089)\end{array}$ & $\begin{array}{c}0.119 \\
(0.0102)\end{array}$ & 0.0521 & * \\
\hline & $\begin{array}{c}\text { MH Anywhere } \\
\text { (S.E.) }\end{array}$ & $\begin{array}{c}0.229 \\
(0.0108)\end{array}$ & $\begin{array}{r}0.23 \\
(0.0132)\end{array}$ & 0.4766 & \\
\hline \multirow[t]{2}{*}{ SECONDARY (NLTS2) } & $\begin{array}{c}\text { MH from School } \\
\text { (S.E.) }\end{array}$ & $\begin{array}{c}0.155 \\
(0.012)\end{array}$ & $\begin{array}{r}0.09 \\
(0.0217)\end{array}$ & 0.0044 & ** \\
\hline & $\begin{array}{c}\text { MH Anywhere } \\
\text { (S.E.) }\end{array}$ & $\begin{array}{c}0.316 \\
(0.015)\end{array}$ & $\begin{array}{c}0.206 \\
(0.0307)\end{array}$ & 0.0006 & $\star \star \star \star$ \\
\hline
\end{tabular}

Source: U.S. Department of Education, Office of Special Education Programs' (OSEP) Special Educational Elementary Longitudinal Study (SEEL); National Longitudinal Transitional Study-2.

Note: Cell values are percentages of the sample whose parents indicated receipt of mental health services. Standard errors below.

$* \mathrm{p}<.05 * * \mathrm{p}<.01 * * * \mathrm{p}<.001$ 
for students with disabilities declined greatly from 2001 to 2005 , based on parent reports. For example, in 2001, of secondary students with disabilities, $31.6 \%$ received mental health services (from any source), but that figure dropped to $20.6 \%$ in 2005 . These trends mirror similar reports regarding funding cutbacks in community mental health and a decline in service provision in recent years (Foster et al., 2005). This portends great difficulties for students with mental health needs at risk for behaviors contributing to school violence and disruption.

\section{MEETING EDUCATIONAL NEEDS OF STUDENTS AND MAINTAINING AN ORDERLY SCHOOL}

A balance must be achieved between (a) protecting the educational rights and opportunities of all students including those with disabilities and (b) the imperative of maintaining a safe, supportive, and productive school environment. Parents, teachers and other professionals, school administrators, and school board members all have a vested interest in seeing equity and safety in how we manage schools and teach children.

\section{Basic Educational Rights}

All 50 states have compulsory school attendance statutes designed to ensure that children receive the benefits of systematic and sustained public education (Verdugo, 2002; Yell, 2006) Students with disabilities are afforded additional protections and rights through the Individuals with Disabilities Education Act (IDEA), including a right to a Free Appropriate Public Education (FAPE). The right to a FAPE includes providing the education at public expense, meeting state education standards, including an appropriate preschool, elementary, or secondary level program in the respective state, and provided in compliance with the student's individualized education plan (IEP). FAPE includes provision of related special education services - an area of controversy and litigation over the years.

In matters of school violence and disruption, and related discipline proceedings, adhering to FAPE requirements has come into conflict with educational imperatives, day-to-day practicalities of running a school and school district, and resource constraints (Tucker, Goldstein, \& Sorenson, 1993). For example, when students with disabilities receive an outof-school suspension or are placed in an Interim Alternative Educational Setting (IAES), schools face challenges in providing meaningful educational supports and FAPE. The courts have issued mixed rulings in cases where provision of FAPE was challenged, based on a minimum number of service hours, commenting that no bright line rule exists.

In one case, an appeals court found that the school district's plan to offer approximately 5 hours per week of instruction, along with other factors in the case, was not a violation of FAPE requirements (Falzett v. Pocono Mountain School District, 1995). The U.S. District Court for Northern Illinois, however, found in favor of the parents' claim that FAPE was not provided because of the 9.5 hours of home instruction delivered over a 22-day period (Community Consolidated School District \#93 v. John F., 2000). In addition to divergent rulings from the courts, factors including limited school district budgets, widespread staff cutbacks, and fully deployed staff have placed severe resource limitations on the ability to respond to these students' needs.

\section{Rights to Fair and Equitable Treatment}

Although state laws and regulations grant general education rights to all youth and IDEA and accompanying regulations grant specific rights to youth with disabilities, in disciplinary matters, there has been a history of bias and unequal treatment relative to race and ethnicity (Gladden, 2002; Harvard University Civil Rights Project, 2000; Skiba, 2000; Verdugo, 2002; Krezmien et al., 2006). For example, Skiba, Michael, Nardo, and Peterson (2002) reported that while African American students did not misbehave to a greater extent than white students, they received disproportionately higher rates of disciplinary referrals from classroom teachers. As documented earlier, significant long-term harm to students' life trajectories occurs as a result of this unfair and biased treatment. The situation is only marginally better for students with disabilities (Leone, Mayer, Malmgren, \& Meisel, 2000; NLTS-2; SEELS, 2001).

A cornerstone of educational philosophy in the United States is access to an equal quality of educational programming for all. Schools systems with a larger proportion of students of color and ethnicity receive the most poorly prepared new teachers (Darling-Hammond, 2000; Metropolitan Life Insurance Company, 2001; Rosenberg \& Sindelar, 2001). Special education teacher preparation studies (Carlson, Schroll, \& Klein, 2001; SPENSE Summary Sheet, 2002) have reported that $65 \%$ of new special education teachers instructed students from a different cultural/linguistic group than themselves. Special educator respondents indicated deficiencies in their skills for meeting the needs of a diverse student population. Furthermore, teacher staffing studies have consistently demonstrated a national shortfall in staff of color and varied ethnicity, especially in special education (Crutchfield, 1997; Donovan \& Cross, 2002; Losen \& Orfield, 2002; Tyler, Yzquierdo, Lopez-Reyna, \& Flippin, 2004).

\section{Disruptions and Interference with the Learning of Self and Others}

A major tenet of strict disciplinary approaches is that misbehaving students do not have the right to deprive other 
students of their right to a quality education. What do we know about interference with learning resulting from classroom and school-based misbehavior? According to the report Indicators of School Crime and Safety, 2000 (Kaufman et al., 2000), "Without a safe learning environment, teachers cannot teach and students cannot learn." The 1993 MetLife survey on school violence mirrors these accounts, reporting that approximately one-third of teachers said that students were less inclined to go to school because of threats of violence. And $50 \%$ of the teachers reported that students were less likely to focus on class instruction because of fears surrounding school violence. One in four students responded that the threat of violence had diminished the quality of their education.

Reviewing studies of students' academic engagement, Walker, Ramsey, and Gresham (2004) reported that, typically, elementary students maintain an academically engaged time (AET) rate of about $70 \%-90 \%$. This contrasts with research showing average AET rates of $60 \%-70 \%$ for a classroom of students with antisocial behavior.

In the National Study of Delinquency Prevention in Schools (Gottfredson et al,, 2000), 27\% of teachers reported that student misbehavior interfered with teaching "a fair amount or a great deal." Likewise, Aleem et al. (1993) reported that, nationally, $44 \%$ of teachers indicated that student behavior problems substantially interfered with teaching. A report by GAO (U. S. General Accounting Office, 2001) found that school respondents cited an undue amount of administrators' and teachers' time consumed by misbehavior. More recently, the 2006 Metropolitan Life Survey of the American Teacher found that, overall, $39 \%$ of teachers reported disorderly student behavior, with higher values $(52 \%)$ in urban/inner city schools and slightly lower values $(35 \%)$ in rural schools.

\section{Student and Teacher Concerns for Maintaining a Safe Learning Environment}

The Metropolitan Life Surveys of the American Teacher shed light on student and teacher attitudes about safety. In the 2006 MetLife Survey, 21\% of teachers nationally indicated that school rules do not help keep order and discipline, and $9 \%$ reported threats by students to teachers and/or staff. Yet, in that same survey, only $4 \%$ of teachers nationally indicated that they did not feel safe at school, with higher rates $(7 \%)$ in urban/inner city schools and lower values $(3 \%)$ in rural schools. When asked (Metropolitan Life Survey, 2004), "what aspects of teaching/being a principal are your greatest sources of stress or anxiety," $1 \%$ of teachers and $3 \%$ of principals responded, "concern about school safety." The three greatest sources of stress and anxiety for both groups were service/duty, students, and parents. When principals were asked what their most important roles were (Metropolitan Life Survey, 2001), about $80 \%$ indicated that the two most important roles were to create a supportive environment, and to maintain discipline and safety.

Students' feelings of safety at school from the mid-1990s through recent years have painted a disturbing picture. The 1993 and 1994 MetLife Surveys found that $49 \%$ and $53 \%$ of students, respectively, felt "very safe" at school. The 2001 MetLife survey reported that $47 \%$ of students felt that their school was "very safe" (as opposed to "somewhat safe" or "not at all safe"). The Metropolitan Life questionnaire format was different in the 2004-05 administration than in earlier versions that asked if students were "very," "somewhat," or "not at all" safe.

In $2004-05$, students responded to the prompt "I feel safe at my current school" along a four-step Likert-type scale of "strongly disagree," "somewhat disagree," "somewhat agree," "strongly agree." In that survey, 73\% of student responded with "somewhat" or "strongly" agree. Unfortunately, we have no easy means of comparing this percentage to earlier patterns of response. Also of interest in the 2004 survey administration are questions surrounding the transition from middle/junior high to high school and perceived safety. Of 7th-9th grade students, $47 \%$ felt safe at their previous school, compared to $29 \%$ who felt safe at their current school.

Another source of information about how students perceive the safety of their schools comes from the report from NCES (DeVoe, Peter, Noonan, Snyder, \& Baum, 2005), which found that for 2003, about $6 \%$ of secondary-age students reported fear of attack at, or while traveling to or from, school. The figure was somewhat higher $(10 \%)$ for urban students than for suburban/rural students (5\%). Students' reports of avoidant behaviors for the same time period indicated that about $5 \%$ of students skipped school or avoided specific locations in school out of fear. The figure was somewhat lower for white students $(3 \%)$ and higher for black $(5 \%)$ and Hispanic students $(6 \%)$.

Finally, data on student perceptions of intimidation and incivility in their school environment must be considered. An emerging body of evidence indicates that a primary source of students' fear and anxiety and related avoidant behaviors in school is the result not of relatively infrequent high-profile threats of injury but, rather, more continuous day-to-day "lower level" forms of incivility and intimidation in schools. Research by Skiba, Simmons, et al. (2004) suggested that school connection and climate, including the degree of incivility, is predictive of students' sense of safety in their schools.

A study of 771 elementary students in an urban and suburban school district found problems with psychosocial functioning associated with exposure to "low-level" aggression (Boxer, Edwards-Leeper, Goldstein, Musher-Eizenman, \& 
Dubow, 2003). Likewise, Mayer (2006) reanalyzed the 1995 , 1999, 2001, and 2003 National Crime Victimization, School Crime Supplement datasets, using structural equation modeling, and found that measures of incivility accounted for far more of the explained variance $(31-45 \%$ versus $17-25 \%)$ in measures of student fear/anxiety, and avoidant behaviors, relative to alternative structural-measurement models using measures of incivility/intimidation, versus high-profile threats of personal harm. These research findings suggest a critical need to further explore linkages among general incivility and intimidation in schools, bullying, students' avoidant behaviors, and prevention programming.

\section{Meeting Students' Needs: A Balanced Approach to Prevention of School Violence and Disruption}

Although school violence can be addressed in many ways, there are limits to what schools alone can do to ameliorate the situation. Larger societal issues are problem areas such as access to guns, exposure to violence in popular media, family-based mental health needs, and the deeper effects of poverty and income inequity. Some of these issues can be addressed through Systems of Care approaches, including wraparound (Burns \& Goldman, 1999; Woodruff, et al., 1999). Amelioration of some problems requires broader social change, but schools can do a great deal to address student needs and reduce the likelihood of violence and disruption. In addition to the more specific school violence prevention approaches discussed previously, one can consider the general goal of providing a healthy, safe, and responsive environment to meet the needs of a diverse student population. Leone and Mayer (2004) posited several recommendations for meeting the educational needs of students at risk for school violence and disruption, including students with disabilities:

\section{Academic instruction and support to ensure success} for all students

While promoting rigorous academic standards and supporting school programs and structures to promote academic progress for the student body as a whole, schools must put in place supports for academically at-risk students to ensure opportunities for student success. These include crafting viable alternatives for students who may need more vocational and transitional supports.

\section{Positive, proactive approaches to school discipline}

Schoolwide, evidence-based practices such as Positive Behavior Supports (PBS) have to be adopted widely. Preservice and inservice training programs for teachers, administrators, and support staff should include in-depth coverage of proactive, schoolwide discipline models. School districts must provide sufficient supports to facilitate infrastructure development and capacity building to achieve these goals. Significant change requires a multi-year implementation plan, ongoing data collection and analysis, strong leadership and broad consensus, and support from the school community.

\section{Embedding opportunities to learn prosocial behaviors} at school

Minimizing school violence and disruption involves changing human behavior. Aggression, a learned behavior, can be unlearned. Students require direct instruction in appropriate replacement behaviors, as well as support and training programs including anger management, social communication skills, social problem solving, and so forth. Critical to future success are authentic opportunities in daily life at school to practice new skills and develop appropriate behaviors. Schools must provide the programming options to address social and emotional issues and offer students a path to learning more prosocial behaviors.

4. Providing multi-service supports in schools to help students at-risk for school failure

Prevention research has indicated the need for multifaceted interventions that address students' needs at multiple ecological levels (i.e., school, peers, neighborhood, family). This implies the need for programs that extend the traditional school mission to teach academics and socialize children. School-based mental health programs are an important component of school-related services. Furthermore, interagency collaboration, using the school as a central point, can facilitate beneficial services from allied agency providers such as social services and juvenile services.

\section{Cultivating a culture of collaboration among all participants}

Stakeholders in children's education should work together to develop improved educational opportunities for students. Shared vision and investment, and consideration for differing philosophies and viewpoints, can foster a productive working relationship. This type of collaboration is what can help at-risk and marginalized students realize success in school and lessen the likelihood of aggressive and violent behaviors.

6. Developing a respectful school community and embracing diversity

Schools have had a troubled history working with students of color and varied ethnicities, as well as students with disabilities. Schools must retool to engage these diverse learners with more sensitivity and respect among staff members, more functional partnerships with parents, and improved approaches to discipline that ensure fair treatment for all. 
7. Data collection, ongoing evaluation, and mid-course corrections

Schools have to use data collection and analysis efficiently to assess their needs, develop appropriate plans, and evaluate and modify programming as necessary. School districts must develop and implement mechanisms for systematic evaluations of comprehensive initiatives designed to promote school safety, foster prosocial behavior, and ensure academic success for all students. High-quality program evaluation can be resource-intensive. This means that schools must receive assistance from federal and state agencies to ensure their capacity to adequately collect and analyze data and modify activities to achieve desired, measurable outcomes.

\section{FUTURE CHALLENGES}

Schools are under increasing pressure to produce results in academic outcome indicators, as well as manage and minimize problems with violence and disruption. The contributing factors related to these challenges mirror many of our societal ills, as discussed throughout this article. Yet, nationally, school systems seemingly are being asked to do more with less.

Research has clearly demonstrated that to prevent school violence, programming at the school level must include a multifaceted approach, with programs meaningfully addressing physical safety, educational practices, and programs that support students' social-emotional-behavioral needs. Research-based violence-prevention and related comprehensive support programs should be offered, using a three tier approach, functioning at the universal, targeted, and intensive levels. Specific areas of programming should include, among others, mental health supports, bully prevention, anger management, and conflict resolution.

Students with disabilities are part of this picture. We know that these students are at elevated risk for suspension from school as well as school failure and dropout. Although some indicators suggest that students with disabilities are being treated in a manner more similar to the larger student population, it is critical for schools to continue to afford this group of students individualized forms of support to foster success in school, with their individualized education plans. Under increased pressures to produce better scores for purposes of NCLB AYP measures, more students will likely be stretched to their limit and, correspondingly, significant behavioral challenges to address. This suggests that schools should reassess their missions and trajectories and proactively develop and institute additional levels of support to help the most at-risk students succeed.

The specter of school violence remains with us, though many indicators, thankfully, have demonstrated substantial declines since the early 1990s. The shocking school-violence incidents of early fall in 2006 reminded Americans that deadly violence can erupt any time and place, and cannot be easily predicted. Through a balanced approach, with widespread stakeholder participation, good communication, efforts to foster connectedness within school and their communities, proactive initiatives to offer students and families appropriate supports, and ongoing data collection and evaluation, we can work collectively to minimize school violence problems in the future.

The authors thank Dr. Reece Peterson of University of Nebraska-Lincoln, and Dr. Stanley Vitello of Rutgers University, for reviewing this manuscript and for the helpful suggestions they provided.

\section{REFERENCES}

Aleem, D., \& others. (1993), Review of research on ways to attain goal six: Creating safe, disciplined, and drug-free schools. Washington, DC: OERI. (ERIC Document Reproduction Service No. ED357446)

Altheide, D. L., \& Michalowski, R. S. (1999). Fear in the news: A discourse of control. Sociological Quarterly, 40(3), 475-503.

American Academy of Pediatrics (2001, November). Media violence. Pediatrics, $108,1222-1226$.

American Bar Association (2001, February). Zero tolerance report. Retrieved September 28, 2006, from http://www.abanet.org/crimjust/ juvjus/zerotolreport.html

American Psychological Association. (1993). Violence and youth: Psychology's response. Washington, DC: Author.

Anderson, C. A., Berkowitz, L., Donnerstein, E., Huesmann, L. R., Johnson, J., Linz, D., Malamuth, N., \& Wartella, E. (2003). The influence of media violence on youth. Psychological Science in the Public Interest, 4(3), 81-110.

Anderson, C. A., \& Bushman, B. J. (2001). Effects of violent video games on aggressive behavior, aggressive cognition, aggressive affect, physiological arousal, and prosocial behavior: A meta-analytic review of the scientific literature. Psychological Science, 12, 353-359.

Annie E. Casey Foundation. (2004). Kids Count Data Book. Baltimore, MD: Author.

Annie E. Casey Foundation. (2006). Kids Count Data Book. Baltimore, MD: Author

Arnette, J.L.. \& Walsleben. M.C. (1998). Combating fear and restoring safety in schools (Bulletin). Washington, DC: U.S. Department of Justice, Office of Justice Programs, Office of Juvenile Justice and Delinquency Prevention.

Ascher, C. (1994). Gaining control of violence in the schools: A view from the field (ERIC Digest No. 100). New York: ERIC Clearinghouse on Urban Education. (ERIC Document Reproduction Service No. ED377256)

Association for Children of New Jersey. (2006). New Jersey kids count 2006. Newark, NJ: Author.

Bear, G. C., Giancola, S. P., Veach, J.. \& Goetz, L. (2006). Beyond face validity: When less is more. In S. Jimerson \& M. J. Furlong (Eds.), The handbook of school violence and school safety: From research to practice (pp. 537-552). Mahwah, NJ: Erlbaum.

Beger, R. (2003). The "worst of both worlds": School security and the disappearing Fourth Amendment rights of students. Criminal Justice Review, 28, 336-354

Biemer, P. P., Groves, R. M., Lyberg, L. E., Mathiowetz, N. A., \& Sudman, S. (1991). Measurement errors in surveys. New York: Wiley.

Bishaw, A., \& Stern, S. (2006). Evaluation of poverty estimates: A comparison of the American Community Survey and the Current Population 
Survey (Background paper). Washington, DC: U.S. Census Bureau, Poverty and Health Statistics Branch, Housing and Household Economic Statistics Division.

Blumstein, A., \& Cork, D. (1996). Linking gun availability to youth gun violence. Law and Contemporary Problems 59(1), 5-24.

Boxer, P., Edwards-Leeper, L., Goldstein. S. E.. Musher-Eizenman, D. R., and Dubow, E. F. (2003). Exposure to "low level" aggression in school: Effects on aggressive behavior, future expectations, and perceived safety. Violence and Victims, 18, 691-704.

Bradley, R. (2003, October). Students with emotional/behavioral disabilities: Data from OSEP's national studies. Paper presented to Council for Children with Behavioral Disorders Annual Conference, St. Louis, MO.

Braga, A. A., \& Kennedy, D. M. (2001). The illicit acquisition of firearms by youth and juveniles. Journal of Criminal Justice, 29, 379-388.

Brooks, K., Schiraldi, V., \& Ziedenberg, J. (2000). School house hype: Two years later. Washington, DC: Justice Policy Institute.

Brotherton, D.C. (1996). The contradictions of suppression: Notes from a study of approaches to gangs in three public high schools. Urban Review, 28(2), 95-117.

Brown, B. (2004). Juveniles and weapons: Recent research, conceptual considerations, and programmatic interventions. Youth Violence and Juvenile Justice, 2(2), 161-184.

Bryan, J., Osendarp, S., Hughes, D., Calvaresi, E., Baghurst, K., \& van Klinken, J. (2004). Nutrients for cognitive development in school-aged children. Nutrition Reviews, 62, 295-306.

Burns, B.J., \& Goldman, S.K. (Eds.). (1999). Promising practices in wraparound for children with serious emotional disturbance and their families. (Systems of Care: Promising Practices in Children's Mental Health, 1998 Series, Vol. IV). Washington, DC: American Institutes for Research Center for Effective Collaboration and Practice.

Bushman, B. J., \& Phillips, C. M. (2001). If the television program bleeds. memory for the advertisement recedes. Current Directions in Psychological Science, 10, $44-47$.

Butts, J., Coggeshall, M., Gouvis, C., Mears, D., Travis, J., Waul, M., et al. (2002). Youth, guns, and the juvenile justice system. Washington. DC Urban Institute.

Cairns, E. (1990). The impact of television news exposure on children's perceptions of violence in Northern Ireland. Journal of Social Psychology: 130(4), 447-452.

Carlson, E., Schroll, K., \& Klein, S. (2001, July). OSEP briefing on the study of personnel needs in special education (SPENSE). Paper presented at the meeting of the OSEP Project Director's Conference. Washington, DC.

Carson, R., Sitlington, P., \& Frank, A. (1995). Young adulthood for individuals with behavioral disorders: What does it hold? Behavioral Disorders, 20, 127-135.

Casella, R. (2003). Zero tolerance policy in schools: Rationale, consequences, and alternatives. Teachers College Record, 105, 872-892.

Center for Communication and Social Policy (1998). National television violence study. Santa Barbara: University of California, Center for Communication and Social Policy.

Center for Schools and Communities. (2001). An evaluation of the school resource officer program: A study of six selected sites from 1998-2000. Lewisburg, PA: Center for Schools and Communities, Central Susquehanna Intermediate Unit. Retrieved August 7. 2002, from http://www. pecd.state.pa.us/Stats/SRO\%20fullrpt.pdf

Centers for Disease Control and Prevention. (1993). Violence-related attitudes and behaviors of high school students: New York City, 1992. Morbidity and Mortality Weekly Report, 42(40), 773-777.

Centers for Disease Control and Prevention. (2006). Web-based injury statistics query and reporting system (WISQARS), U.S Department of Health and Human Services, CDC, National Center for Injury Prevention and Control. Available at www.cdc.gov/ncipc/wisqars. Accessed September 25, 2006.

Centers for Disease Control and Prevention. Youth violence fact sheet. Retrieved September 25, 2006, from http://www.cdc.gov/ncipc/factsheets/yvfacts.htm

Chen. S., Chang, K., \& Tombs, B.S. (1999), An evaluation of school resource officer program in Kansas. Topeka: Kansas Criminal Justice
Coordinating Council. Retrieved August 7, 2002, from http://www. state.ks.us/public/ksc/sroreport.PDF

Colwell, M. J., Meece, D., Pettit, G. S., Bates, J. E., \& Dodge, K.A. (2001). Developmental Risk and Continuity in Nonparental Care from infancy to early adolescence. Merrill Palmer Quarterly, 47, 207-234.

Community Consolidated School District No. 93 v. John F. 33 IDELR 210 (N.D. IL, 2000)

Cook, P. J., \& Laub, J. H. (1998). The epidemic in youth violence. In M. Tonry \& M. H. Moore (Eds.), Youth violence (pp. 27-64). Chicago: University of Chicago Press.

Cook, P. J. \& Ludwig, J. (1997, May). Guns in America: National survey on private ownership and use of firearms (Research Brief NIJ Rep. No. NCJ-165476). Washington, DC: U.S. Department of Justice, National Institute of Justice.

Cook, P. J., \& Ludwig, J. (2004). Does gun prevalence affect teen gun carrying after all? Criminology, 42, 27-54.

Cornell, D., Sheras, P.L., \& Cole, J.C.M. (2006). Assessment of bullying. In S.R. Jimerson \& M.J. Furlong (Eds.), Handbook of school violence and school safety: From research to practice. (pp. 191-209). Mahwah, NJ: Erlbaum.

Cornell, D., Sheras, P.. Kaplan, S., Levy-Elkon, A., McConville, D. McKnight, L., \& Posey, J. (2004). Guidelines for responding to student threats of violence: Field test of a threat assessment approach. In M. J. Furlong, P. M. Bates, D. C., Smith, \& P. M. Kingery, P.M. (Eds.) Appraisal and prediction of school violence: Methods, issues and contents (pp. 11-36). Hauppauge, NY: Nova Science Publishers.

Cornell, D, \& Williams, F. (2006). Student threat assessment as a strategy to reduce school violence. In S.R. Jimerson \& M.J. Furlong (Eds.), The handbook of school violence and school safety: From research to practice (pp. 587-601). Mahwah. NJ: Erlbaum.

Cross, J.E., \& Newman-Gonchar, R. (2004). Data quality in student risk behavior surveys and administrator training. Journal of School Violence, 3, 89-108.

Crutchfield, M. (1997). Who's teaching our children with disabilities? Washington, DC: National Information Center for Children and Youth with Disabilities. Retrieved August 2, 2002, from http://www.nichcy. org/pubs/newsdig/nd27.pdf

Cunningham, P. B., Henggeler, S. W., Limber. S. P., Melton, G. B., \& Nation, M. A. (2000). Patterns and correlates of gun ownership among non-metropolitan and rural middle school students. Journal of Child Clinical Psychology, 29, 432-442.

Darling-Hammond, L. (2000, January 1). Teacher quality and student achievement: A review of state policy evidence. Education Policy Analysis Archives. Retrieved August 2, 2002, from http://epaa.asu. edu/epaa/v8n1/

Delizonna, L., Alan, I., \& Steiner, H. (2006). A case example of a school shooting: Lessons learned in the wake of tragedy. In S.R. Jimerson \& M.J. Furlong (Eds.), Handbook of school violence and school safety: From research to practice (pp. 617-629). Mahwah, NJ: Erlbaum.

Derksen, D.J., \& Strasburger, V.C. (1996). Media and television violence: Effects on violence, aggression, and antisocial behaviors in children. In A.M. Hoffman (Ed.), Schools, violence, and society (pp. 61-77). Westport, CT: Praeger.

DeVoe, J.F., Peter, K., Noonan, M., Snyder, T.D., \& Baum. K. (2005). Indicators of school crime and safety: 2005 (NCES 2006-001/NCJ 210697). Washington, DC: U.S. Departments of Education and Justice.

DiGuiseppi, C., Mytton, J., Gough, D., Taylor, R., \& Logan, S. (2002) School-based violence prevention programs: Systematic review of secondary prevention trials. Archives of Pediatric \& Adolescent Medicine. $156(8), 752-762$

Dinkes, R., Cataldi, E.F., Kena, G., \& Baum, K. (2006). Indicators of School Crime and Safety: 2006 (NCES2007-003/NCJ 214262). Washington. DC: U.S. Departments of Education and Justice.

Donovan, M. S., \& Cross, C. T. (2002). Minority students in special and gifted education. Washington, DC: National Academy Press.

Eisert, A. (2005a, September). School resource officer evaluation: Executive summary. Camp Hill, PA: Center for Schools and Communities.

Eisert, A. (2005b, September). School resource officer evaluation: Phase two. Camp Hill, PA: Center for Schools and Communities. 
Elliott, D., Hamburg, B., \& Williams, K. (Eds.). (1998). Violence in American schools. New York: Cambridge University Press.

Falzett v. Pocono Mountain Sch. Dist., 2005 U.S. App. LEXIS 22005 (3rd Cir. 2005).

Farrington, D.P. (2005). Early identification and preventive intervention: How effective is this Strategy? Criminology and Public Policy, 4. 237-248.

Federal Interagency Forum on Child and Family Statistics. (2005). America's children: Key national indicators of well-being, 2005. Washington, DC: U.S. Government Printing Office.

Federal Interagency Forum on Child and Family Statistics.(2006). America's children in brief: Key national indicators of well-being. 2006 (Table POP8.C). Federal Interagency Forum on Child and Family Statistics. Washington, DC: U.S. Government Printing Office.

Fein, R., Vossekuil, B., Pollack, W., Borum, R., Modzeleski, W., \& Reddy, M. (2002). Threat assessment in schools: A guide to managing threatening situations and to creating safe school climates. U.S. Department of Education. Office of Elementary and Secondary Education. Safe and Drug-Free Schools Program and U.S. Secret Service, National Threat Assessment Center, Washington, DC

Felson, R. B. (1996). Mass media effects on violent behavior. Annual Review of Sociology, 22, 103-128.

Foster, A., \& Vizzard, L. H. (2000, July). Final report: School resource officer partnership evaluation. Ft. Collins, CO: Poudre School District. Retrieved August 7, 2002, from http://www.colostate.edu/depts/rdcenter/sroevaluation2000.pdf

Foster, S., Rollefson, M., Doksum, T., Noonan, D., Robinson, G., \& Teich, J. (2005). School mental health services in the United States, 2002-2003 (DHHS Pub. No. (SMA) 05-4068). Rockville, MD: Center for Mental Health Services, Substance Abuse and Mental Health.

Frey, K.S., Hirschstein, M.K., \& Guzzo, B. (2000). Second step: Preventing aggression by promoting social competence. Journal of Emotional and Behavioral Disorders, 8(2), 102-112.

Furlong, M. J. Bates, S. P., \& Smith, D. C. (2001). Predicting school weapon possession : A secondary analysis of the Youth Risk Behavior Surveillance Survey. Psychology in the Schools, 38, 127-140.

Furlong, M. J., Bates, M. P., Smith, D. C., \& Kingery, P. (Eds.). (2004). Appraisal and prediction of school violence: Issues, methods and contexts. Hauppauge, NY: Nova Science Publishers.

Furlong, M. J.. Morrison, G. M.. Skiba, R.. \& Cornell, D. (Eds.). (2004). Issues in School Violence Research. New York: Haworth Press.

Furlong. M. J.. \& Sharkey. J. D. (2006). A review of methods to assess student self-report of weapons on school campuses. In S. R. Jimerson \& M. J. Furlong (Eds.), Handbook of school violence and school safety: From research to practice (pp. 235-256). Mahwah, NJ: Lawrence Erlbaum Associates.

Furlong, M. J., Sharkey, J. D., Bates, M. P., Smith, D. C. (2004). An examination of the reliability, data screening procedures, and extreme response patterns for the Youth Risk Behavior Surveillance Survey. Journal of School Violence, 3(2/3), 109-130.

Gagnon, J.C., \& Leone, P.E. (2001, Winter). Alternative strategies for school violence prevention. In R. J. Skiba \& G. G. Noam (Eds.), Zero tolerance: Can suspensions and expulsion keep schools safe? (pp. 101-125). San Francisco: Jossey-Bass.

Gerbner, G. (1988). Violence and terror in the mass media (Reports and Papers on Mass Communications, no. 102). Paris: UNESCO.

Gladden, M. (2002). Reducing school violence: Strengthening student programs and addressing the role of school organizations. Review of Research in Education 26, 263-297.

Gotbaum, B. (2002. November 21). Pushing out at-risk students: An analysis of high school discharge figures (Report by the Public Advocate for the City of New York and Advocates for Children). New York: Advocates for Children.

Gottfredson, G.D., Gottfredson, D.C., Czeh, E.R., Cantor, D.. Crosse, S.B., \& Hantman, I. (2000). National study of delinquency prevention in schools [Summary rep.]. Ellicott City, MD: Gottfredson.

Green, M. (1999). The appropriate and effective use of security technologies in US schools: A guide for schools and law enforcement agencies (NCJ 178265). Washington, DC: National Institute of Justice.
Greenbaum, P. E., Dedrick, R. F., Friedman, R. M., Kutash, K., Brown, E. C., Lardieri, S. P., \& Pugh, A. M. (1996). National Adolescent and Child Treatment Study (NACTS): Outcomes for children with serious emotional and behavioral disturbance. Journal of Emotional and Behavioral Disorders, 4, 130-146.

Gun-Free Schools Act, 20 U.S.C. \$ 1415 (e) (3).

Haider-Markel, D. P., \& Joslyn, M. R. (2001) Gun policy, opinion, tragedy, and blame attribution: The conditional influence of issue frames. Journal of Politics, 63(2), 520-543.

Harvard University Civil Rights Project. (2000). Opportunities suspended: The devastating consequences of zero tolerance and school discipline policies. Retrieved July 30, 2002, from http://www.law.harvard.edu/ groups/civilrights/conferences/zero/zt_report2.html

Hawkins, J. D., Farrington, D. P., \& Catalano, R. F. (1998), Reducing violence through the schools. In D. S. Elliott, B. A. Hamburg, \& K. R. Williams (Eds.), Violence in American schools (pp. 188-216). New York: Cambridge University Press.

Hawkins, J. D., Herrekohl, T., Farrington, D. P., Brewer, D., Catalano, R. F., \& Harachi, T. W. (1998). A review of predictors of youth violence. In R. Loeber \& D. P. Farrington (Eds.), Serious \& Violent Juvenile Offenders (pp. 106-146). Thousand Oaks, CA: Sage.

Hernandez, D. J. (1995). Changing demographics: Past and future demands for early childhood programs. The Future of Children. 5(3), 145-160.

Heubert, J. (2002). Disability, race, and high-stakes testing of students. In D. Losen \& G. Orfield, (Eds.), Racial inequity in special education (pp. 123-152). New York: Century Fund.

Hoagwood, K., \& Johnson. J. (2003). School psychology: A public health framework I. From evidence-based practices to evidence-based policies. Journal of School Psychology, 41, 3-21.

Howard, H. H. (1998). The 1996 Telecommunications Act and TV stations ownership: 1 year later. Journal of Media Economics, II(3), 21-32

Huesmann, L.. Moise-Titus J., Podolski. C., \& Eron, L. (2003). Longitudinal relations between children's exposure to TV violence and their aggressive and violent behavior in young adulthood. Developmental Psychology, 39(2), 201-221.

Humphrey, J. A. (2001). School resource officer evaluation: Executive summary. Durham: University of New Hampshire, Justiceworks. Retrieved August 7, 2002, from http://www.justiceworks.unh.edu/Research/ SRO_Eval/sro_eval.html

Individuals With Disabilities Education Improvement Act of 2004, 20 U.S.C. $33 \$ 1400$ et seq.

Jimerson, S. R., \& Brock, S. E. (2004). Threat assessment, school crisis preparation, and school crisis response. In M. J. Furlong. P. M. Kingery, \& M. P. Bates (Eds.), Appraisal and prediction of school violence: Context, issues, and methods (pp. 67-87). Hauppauge, NY: Nova Science.

Jimerson, S. R., \& Furlong, M. J. (Eds.). (2006). Handbook of school violence and safety. Englewood Cliffs, NJ: Lawrence Earlbaum.

Johnson, I. M. (1999). School violence: The effectiveness of a school resource officer program in a southern city. Journal of Criminal Justice, 27(2), 173-192.

Juvonen, J. (2001). School violence: Prevalence, fears, and prevention (RAND Issue Paper No. IP-219-EDU). Santa Monica, CA: RAND Education. Retrieved January, 12, 2002, from http://www.rand.org/ publications/IP/IP219/

Kaufman, P., Chen, X.. Choy, S. P., Ruddy, S. A., Miller, A. K.. Fleury, J. K., Chandler, K. A., Rand, M. R., \& Klaus, P., \& Planty, M. G. (2000). Indicators of school crime and safety, 2000 (NCES 2001-017) NCJ-184176). Washington, DC: U.S. Departments of Education and Justice. Kerrebrock, N., \& Lewit, E. M. (1999). Children in self-care. The Future of Children, 9(2), 151-160.

Kerrebrock, N., \& Lewit, E. M. (1999). Child indicators: Children in selfcare. Future of Children, 9(2) 151-160.

Klopovic, J., McDaniel, J., Sullivan, B., Vasu, E. S., \& Vasu, M. L. (1996). Preventing school violence by helping communities help childrenSchool resource officers: An analysis overview. CITY, NC: Governor's Crime Commission.

Kostinsky, S., Bixler, E., \& Kettl, P. (2001). Threats of school violence in Pennsylvania after media coverage of the Columbine High School 
massacre: Examining the role of imitation. Archives of Pediatrics and Adolescent Medicine, 155, 994-1001.

Krezmien, M.P., Leone, P.E., \& Achilles, G.M. (2006). Suspension, race, and disability: Analysis of state-wide practices and reporting. Journal of Emotional and Behavioral Disorders, 14, 217-226.

Kunkel, D., Smith, S., Suding, P., \& Biely, E. (2002, February). Coverage in context: How thoroughly the news media report five key children's issues. College Park, MD: University of Maryland, Philip Merrill College of Journalism, Casey Journalism Center on Children and Families.

Langenfeld, K. L., Thurlow, M. L., \& Scott, D. L. (1997). High stakes testing for students: Unanswered questions and implications for students with disabilities (Synthesis Rep. No. 26). Minneapolis: University of Minnesota, National Center on Educational Outcomes. Retrieved July 17, 2002, from http://education.umn.edu/NCEO/OnlinePubs/Synthe sis $26 . \mathrm{html}$

Lauritsen, J. (2003). How Families and Communities Influence Youth Victimization (OJJDP Bulletin, \# NCJ 201629, November). Washington, DC: U.S. Office of Juvenile Justice and Delinquency Prevention.

Lehr, C. A., Johnson, D. R., Bremer, C. D., Cosio, A., \& Thompson, M. (2004, May). Essential tools: Increasing rates of school completion: Moving from policy and research to practice: A manual for policymakers, administrators, and educators. Minneapolis: University of Minnesota, National Center on Secondary Education and Transition, Institute on Community Integration.

Leone, P. E., \& Mayer, M. J. (2004). Safety, diversity, and disability: "Goodness of fit" and the complexities of the school environment. In M. J. Furlong, M. P. Bates, \& P. Kingery (Eds.), Best practices in school-based threat assessment (pp. 135-163). Hauppauge, NY: Nova Science Publishers.

Leone, P. E., Mayer, M. J., Malmgren, K., \& Meisel, S. M. (2000). School violence and disruption: Rhetoric, reality, and reasonable balance. Focus on Exceptional Children, 33(1), 1-20.

Lichter, S. R., Lichter, L. S.. \& Amundson, D. (1999). Merchandizing mayhem: Violence in popular culture. Washington, DC: Center for Media and Public Affairs.

Losen, D. J.. \& Orfield, G. (2002). Racial inequity in special education (Civil Rights Project at Harvard University). Cambridge, MA: Harvard University Press

Luiselli, J. K., Putnam, R. F., \& Sunderland, M. (2002). Longitudinal evaluation of behavior support intervention in a public middle school. Journal of Positive Behavior Interventions, 4, 182-188.

Marsh, H. L. (1991). A comparative analysis of crime coverage in newspapers in the United States and other countries from 1960-1989: A review of the literature. Journal of Criminal Justice, 19, 67-80.

Mayer, M. J. (2006, November). Structural analysis of school violence data: School strategies and students' anxiety/avoidance. Paper presented to Teacher Educators for Children with Behavior Disorders Conference, Tempe, AZ.

Mayer, M. J., \& Leone, P. E. (1999). A structural analysis of school violence and disruption: Implications for creating safer schools. Education and Treatment of Children, 22, 333-358.

McCurley, C., \& Snyder, H. (in press). Risk, protection, and family structure (OJJDP Juvenile Justice Bulletin). Washington. DC: U.S. Department of Justice, Office of Justice Programs, Office of Juvenile Justice and Delinquency Prevention.

McDevitt, J., \& Panniello, J. (2005). National assessment of school resource officer programs: Survey of students in three large new SRO programs (NCJ 209270). Washington, DC: National Institute of Justice, National Criminal Justice Reference Service.

Menifield, C. E., Rose, W. H., Homa, J., \& Cunningham, A. B. (2001). The media's portrayal of urban and rural school violence: A preliminary analysis. Deviant Behavior, 22, 447-464.

Mercy, J. A., \& Rosenberg, M. L. (1998). Preventing firearm violence in and around schools. In D. S. Elliott, B. A. Hamburg, \& K. R. Williams (Eds.), Violence in American schools (pp. 159-187). New York: Cambridge University Press.

Metropolitan Life Insurance Company. (1993). Metropolitan Life survey of the American teacher: Violence in America's public schools, 1993. New York: Author.
Metropolitan Life Insurance Company. (1994). Metropolitan Life survey of the American teacher: Violence in America's public schools: The family perspective, 1994. New York: Author.

Metropolitan Life Insurance Company. (2001). Metropolitan Life survey of the American teacher, 2001: Key elements of quality schools. New York: Author.

Metropolitan Life Insurance Company. (2004). Metropolitan Life survey of the American teacher, 2004: Transitions and the role of supportive relationships. New York: Author.

Metropolitan Life Insurance Company. (2006). Metropolitan Life survey of the American teacher, 2006: Expectations and experiences. New York: Author.

Michigan Nonprofit Association. (2003, January). Zero tolerance policies and their impact on Michigan students (Spotlight Series on Applied Research). East Lansing: Michigan State University, Institute for Children, Youth and Families.

Morrison, G. M., Peterson, R., O'Farrell, S., \& Redding, M. (2004). Using office referral records in school violence research: Possibilities and limitations. Journal of School Violence, 3(2/3), 39-61.

Morrison, G.M., Redding, M., Fisher, E., \& Peterson, R. (2006). Assessing school discipline. In S.R. Jimerson \& M.J. Furlong (Eds.), Handbook of school violence and school safety: From research to practice (pp. 211-220). Mahwah, NJ: Erlbaum.

Murnan, J., Dake, J. A., \& Price, J. H. (2004). Association of selected risk factors with variation in child and adolescent firearm mortality by state. Journal of School Health, 74(8), 335-340.

Mytton, J., DiGuiseppi, C., Gough, D., Taylor, R., \& Logan, S. (2006). School-based secondary prevention programmes for preventing violence. Cochrane Database of Systematic Reviews 2006, Issue 3, Art. no. CD004606. DOI: 10.1002/14651858.CD004606.pub2.

Nagaoka, J., \& Roderick, M. (2004). Ending social promotion: The effects of retention. Chicago: Consortium of Chicago School Research. Retrieved February 19, 2007, from http://ccsr.uchicago.edu/publications/p70.pdf

National Association of State Boards of Education. (2006, May). High school exit exams. NASBE Policy Update, vol. 14, no. 7. Alexandria, VA: Author.

The National Commission on Excellence in Education (1983). A Nation at Risk: The Imperative for Educational Reform. Retrieved December 6 , 2007 from http://www.ed.gov/pubs/NatAtRisk/index.html

National Longitudinal Transition Study-2. NLTS2 Data Tables. Retrieved January 12, 2007, from http://www.nlts2.org/data tables/index.html

National Research Council and Institute of Medicine. (2003). Deadly lessons: Understanding lethal school violence. Case studies of school violence committee (Mark H. Moore, Carol V. Petrie, Anthony A. Braga, \& Brenda L. McLaughlin, Eds.). Washington, DC: National Academies Press, Division of Behavioral and Social Sciences and Education.

National School Safety Center. (2006). School associated violent deaths. Retrieved September 25, 2006, from http://www.schoolsafety.us/ School-Associated-Violent-Deaths-p-6.html

Nelson, J. R.,Martella, R., \& Galand, B. (1998). The effects of teaching school expectations and establishing a consistent consequence on formal office disciplinary actions. Journal of Emotional and Behavioral Disorders, 6, 153-161.

Nersesian, M., Todd, A., Lehmann, J., \& Watson, J. (2000). School-wide behavior support through district-level system change. Journal of Positive Behavior Interventions, 2, 244-247.

No Child Left Behind Act of 2001, P.L. 107-110, 115 Stat. 1425 (2002).

Noguera, P. A. (1995). Preventing and producing violence: A critical analysis of responses to school violence. Harvard Educational Review. $65(2), 189-212$

Office of the New York State Comptroller. (2006). Reporting of violent and disruptive incidents by public schools (Rep. 2005-S-38). Albany, NY: Author.

Okoro, C. A., Nelson, D. E., Mercy, J. A., Balluz, L. S., Crosby, A. E., \& Mokdad, A. H. (2005). Prevalence of household firearms and firearmstorage practices in the 50 states and the District of Columbia: Findings from the Behavioral Risk Factor Surveillance System, 2002. Pediatrics, 116(3), 370-376. 
Orfield, G., Losen, D., Wald, J., \& Swanson, C. B. (2004), Losing our future: How minority youth are left behind by the graduation crisis. Cambridge, MA: Harvard University, Civil Rights Project.

Osher, D.. Dwyer, K., \& Jimerson, S. (2006). Safe, supportive, and effective schools: Promoting school success to reduce school violence. In S. Jimerson \& M. Furlong. (Eds.). Handbook of school violence and school safety: From research to practice (pp. 51-71). Mahwah, NJ: Lawrence Erlbaum Associates.

Peterson, R. L., Larson, J., \& Skiba, R. (2001). School violence prevention: Current status and policy recommendations. Law \& Policy, 23(3). $345-371$.

Pressley, M., \& McCormick, C. B. (2007). Child and adolescent development for educators. New York: Guilford Press.

Project for Excellence in Journalism. (2006). 2006 annual report on the state of the news media. Washington. DC: Author.

Quenemoen, R. F., Lehr, C. A., Thurlow, M. L., Thompson, S. J., \& Bolt, S. (2000). Social promotion and students with disabilities: Issues and challenges in developing state policies (Synthesis Rep. No. 34), Minneapolis: University of Minnesota. National Center on Educational Outcomes. Retrieved July 17, 2002, from http://education.umn. edu/NCEO/OnlinePubs/Synthesis $34 . \mathrm{html}$

Reardon, S. F., \& Galindo, C. (2002, April). Do high-stakes tests affect students' decisions to drop out of school? Evidence from NELS. Paper presented to the American Educational Research Association, New Orleans, LA.

Reddy, M., Borum. R., Berglund, Vossekuil, Fein, \& Modzeleski, W. (2001). Evaluating risk for targeted violence in schools: Comparing risk assessment, threat assessment, and other approaches. Psychology in the Schools, 38, 157-172.

Reddy-Randazzo, M., Borum, R.. Vossekuil, B.. Fein, R., Modzeleski. W.. \& Pollack, W. (2006). In S. R. Jimerson \& M. J. Furlong (Eds.), Handbook of school violence and school safety: From research to practice (pp. 147-156). Mahwah, NJ: Lawrence Erlbaum Associates.

Reiss, A. J. \& Roth, J. A. (Eds.). (1993). Understanding and preventing violence. Washington, DC: National Academy Press.

Reza, A., Modzeleski, W., Feucht, T., Anderson, M., Simon, T. R., \& Barrios, L. (2003). Sources of firearms used by students in school-associated violent deaths-United States, 1992-1999. Morbidity and Mortality Weekly Report (2003), 52, 169-172.

Richart, D.. Brooks, K., \& Soler, M. (2003). Unintended consequences: The impact of "Zero Tolerance" and other exclusionary policies on Kentucky students. Retrieved September 28, 2006, from http://www. buildingblocksforyouth.org

Rideout, V., Vandewater, E., \& Wartella, A. (2003). Zero to six: Electronic media in the lives of infants, toddlers and preschoolers. Menlo Park. CA: Kaiser Family Foundation.

Rosenberg, M. S., \& Sindelar, P. T. (2001). The proliferation of alternative routes to certification in special education: A critical review of the literature. Arlington. VA: National Clearinghouse for Professions in Special Education, Council for Exceptional Children. Retrieved August 1, 2002, from hitp://www.special-ed-careers.org/pdf/altcert. pdf

Safra, S. J. (2000, November). The amended Gun-Free School Zones Act: Doubt as to its constitutionality remains. Duke Law Journal, 50(2). 637-662.

Sampson, R. J., \& Lauritsen. J. L. (1994). Violent victimization and offending: Individual, situational, and community-level risk factors. In A. J. Reiss Jr. \& J. Roth (Eds.), Understanding and preventing violence: Social influences (Vol. 3, pp. 1-114). Washington, DC: National Academy Press.

Schiraldi, V., \& Zeidenberg. J. (2001. September). Schools and suspensions: Self-reported crime and the growing use of suspensions (Justice Policy Institute Policy Brief). Washington, DC: Justice Policy Institute.

Schneider, T. (2001). Newer technologies for school security (ERIC Digest No. 145). Eugene, OR: ERIC Clearinghouse on Educational Management. (ERIC Document Reproduction Service No. ED449550)

Schuster, M.A. Franke, T.M., Bastian, A.M., Sor, S.. \& Halfon, N. (2000). Firearm storage patterns in US homes with children. American Journal of Public Health, 90(4), 588-594.
Sharkey, J. D., Furlong, M. J., \& Yetter, G. (2006). An overview of measurement issues in school violence and school safety research. In S. R. Jimerson \& M. J. Furlong (Eds.), Handbook of school violence and school safety: From research to practice (pp. 121-134). Mahwah, NJ: Lawrence Erlbaum Associates.

Sheley, J. F., McGee, Z. T., \& Wright, J. D. (1995). Weapon-related vicrimization in selected inner-city high school samples. Washington, DC: National Institute of Justice.

Sheley, J. F., \& Wright, J. D. (1998, October). High school youth, weapons, and violence: A national survey. Washington, DC: National Institute of Justice.

Shepard, L. A. (1991). Will national tests improve student learning? (CSE Tech. Rep. No. 342). Los Angeles: National Center for Research on Evaluation, Standards, and Student Testing.

Skiba, R. J. (2000, August). Zero tolerance, zero sense: An analysis of school disciplinary practice. (Policy Research Rep. No. SRS2). Bloomington: Indiana Education Policy Center.

Skiba, R. J. (2004). Zero tolerance: The assumptions and the facts (Education Policy Brief, 2(1). Bloomington: Indiana University Center for Evaluation and Policy.

Skiba, R. J. \& Leone. P.E. (2001). Zero tolerance and school security measures: A failed experiment. In T. Johnson. J.E. Boyden, \& W.J. Pittz (Eds.), Racial profiling and punishment in U.S. public Schools: How zero tolerance policies and high stakes testing subvert academic excellence and racial equity. Oakland, CA: Applied Research Center.

Skiba, R. J., Michael. R. S., Nardo, A. C.. \& Peterson. R. (2002). The color of discipline: Sources of racial and gender disproportionality in school punishment. Urban Review, 34(4), 317-342.

Skiba, R. J., \& Peterson, R. L. (1999). The dark side of zero tolerance: Can punishment lead to safe schools? Phi Delta Kappan, 80(5), 372-378.

Skiba, R. J., \& Peterson, R. L. (2000). School discipline at a crossroads: From zero tolerance to early response. Exceptional Children, 66(3), 335-347.

Skiba, R.J., Ritter, S., Simmons, A.B., Peterson, R., \& Miller, C. (2006), The safe and responsive schools project: A school reform model for implementing best practices in violence prevention. In S.R. Jimerson \& M.J. Furlong (Eds.), Handbook of school violence and school safety: From research to practice (pp. 631-650). Lawrence Erlbaum Associates.

Skiba, R.J., Simmons, A.B., Peterson, R., McKelvey, J., Forde, S., \& Gallini, S. (2004). Beyond guns, drugs and gangs: The structure of student perceptions of school safety. Journal of School Violence, 3(2/3). 149-171.

Snell, L. (2005, January). School violence and No Child Left Behind: Best practices to keep kids safe. Los Angeles: Reason Foundation.

Snyder, H. N., \& Sickmund, M. (2006). Juvenile offenders and victims: 2006 National report. Washington, DC: U.S. Department of Justice, Office of Justice Programs, Office of Juvenile Justice and Delinquency Prevention.

Snyder, T. D. Tan, A. G., and Hoffman. C. M. (2006). Digest of Education Statistics 2005 (NCES 2006-030). Washington, DC: U.S. Department of Education, National Center for Education Statistics.

Special Educational Elementary Longitudinal Study. SEELS Data Tables Overview. Retrieved January 12, 2007, from http://seels.net/search/ datatableOverview.htm

SPENSE Summary Sheet. (2002). Beginning special educator: Characteristics, qualifications, and experiences. Retrieved August 1, 2002, from http://www.spense.org/ IHEsummaryfinal.pdf

Stolzenberg, L., \& D’Alessio, S. (2000). Gun availability and violent crime: New evidence from the National Incident-Based Reporting System. Social Forces, 78, 1461-1482.

Thompkins, D. (2000). School violence: Gangs and a culture of fear. Annals of American Academy of Political and Social Science, 567. 54-71.

Tucker, B. P.. Goldstein, B. A., \& Sorenson. G. (1993). The educational rights of children with disabilities: Analysis, decisions and commentary. Horsham. PA: LRP.

Tyler, N. C., Yzquierdo, Z., Lopez-Reyna, N., \& Flippin, S. S. (2004). Cultural and linguistic diversity in the special education workforce: A critical overview. Journal of Special Education, 38(1), 22-38. 
United States. (2004). Keeping schools safe: The implementation of No Child Left Behind's persistently dangerous schools provision. Field hearing before the Subcommittee on Education Reform of the Committee on Education and the Workforce, U.S. House of Representatives, One Hundred Eighth Congress, first session. September 29, 2003, in Denver, CO. Washington, DC: U.S. Government Printing Office. United States v. Lopez, 115 S. Ct. 1624 (1995).

U.S. Census Bureau. (2005, August 30). News conference on 2004 income. poverty, and health insurance estimates from the Current Population Survey (Charles Nelson, Assistant Division Chief, Housing and Household Economic Statistics, U.S. Census Bureau). Retrieved February 16, 2007, from http://www.census.gov/hhes/www/income/income04/ prs05asc.html

U.S. Department of Education, National Center for Education Statistics. (2006). The condition of education 2006 (NCES 2006-071). Washington, DC: U.S. Government Printing Office.

U.S. Department of Education, Office of Elementary and Secondary Education and Planning and Evaluation Service. (1998). Report on state implementation of the Gun-Free Schools Act-school year 1996-97 (Contract No. EA9405200I, prepared by Westat, Rockville, MD). Washington, DC: U.S. Government Printing Office.

U.S. Department of Education, Office of Safe and Drug-Free Schools (2006). Report on the implementation of the Gun-Free Schools Act of 1994 in the states and outlying areas for school Year 2002-03. Washington, DC: U.S. Government Printing Office.

U.S. Department of Education, Office of Special Education and Rehabilitative Services, Office of Special Education Programs. (2006). 26th annual (2004) Report to Congress on the implementation of the Individuals with Disabilities Education Act (Vol. 1). Washington, DC: U.S. Government Printing Office.
U.S. Department of Health and Human Services. (2001). Youth violence: A report of the Surgeon General. Rockville, MD: U.S. Department of Health and Human Services.

U.S. General Accounting Office (2001). Student discipline: Individuals with disabilities in education act (GAO Report No. GAO-01-210). Washington, DC: U.S. General Accounting Office.

U.S. National Commission on Excellence in Education. (1983). A nation at risk: The imperative for educational reform: A report to the nation and the secretary of education. Washington, DC: U.S. Department of Education.

United States v. Lopez (93-1260), 514 U.S. 549 (1995)

Vacha, E. F., \& McLaughlin, T. F. (2004). Risky firearms behavior in low income families of elementary school children: The impact of poverty, fear of crime, and crime victimization on keeping and storing firearms. Journal of Family Violence, 19, 175-184.

Van Dyke, R., Ryan-Arredondo, K., Rakowitz, B., \& Torres, J. L. (2004). The Dallas Independent School District's threat assessment procedures: Summary of findings after four years of implementation. In M. J. Furlong, P. M. Bates, D. C., Smith, \& P. M. Kingery, P.M. (Eds.), Appraisal and prediction of school violence: Methods, issues and contents (pp. 37-62). Hauppauge, NY: Nova Science Publishers.

Vandivere, S., Tout, K., Zaslow, M., Calkins, J., \& Capizzano, J. (2003). Unsupervised time: Family and child factors associated with self-care (Assessing the New Federalism, Occasional Paper No. 71). Washington, DC: Urban Institute,

Verdugo, R. R. (2002). Race-ethnicity, social class, and zero-tolerance policies. Education and Urban Society, 35(1), 50-75.

Virginia State Department of Criminal Justice Services. (2000). Evaluation of grant funded school resource officer programs. Richmond, VA: Author.

\section{Challenging the Refusal of Reasoning in Special Education}

Mark P. Mostert $=$ Kenneth A. Kavale $\mathbf{m}$ James M. Kauffman

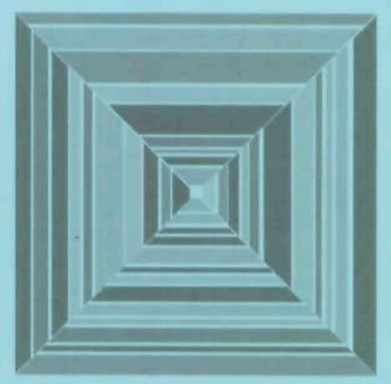

This text intervenes in the debate currently raging across academic disciplines between postmodern theory and Enlightenment thought. It responds directly to the call for a postmodern approach to special education with an impassioned defense of the precepts of science against the threats of relativism. The book marshals a series of essays to argue that the liberatory approach to special education is a clear danger to the children it is intended to serve. It refutes the call for a total rejection of the scientific method as well as the more subtle ways postmodern thinking undermines science by preferring moral imperatives to objective facts.

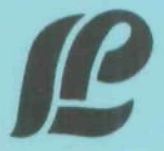

NEW! / 304 pages / paperback / $\$ 52.00$

Love Publishing Company

9101 E. Kenyon Ave., Suite 2200

Denver, CO 80237

303-221-7333 - 303-22212-7444 (fax)

ISBN 978-0-89108-329-0 
28

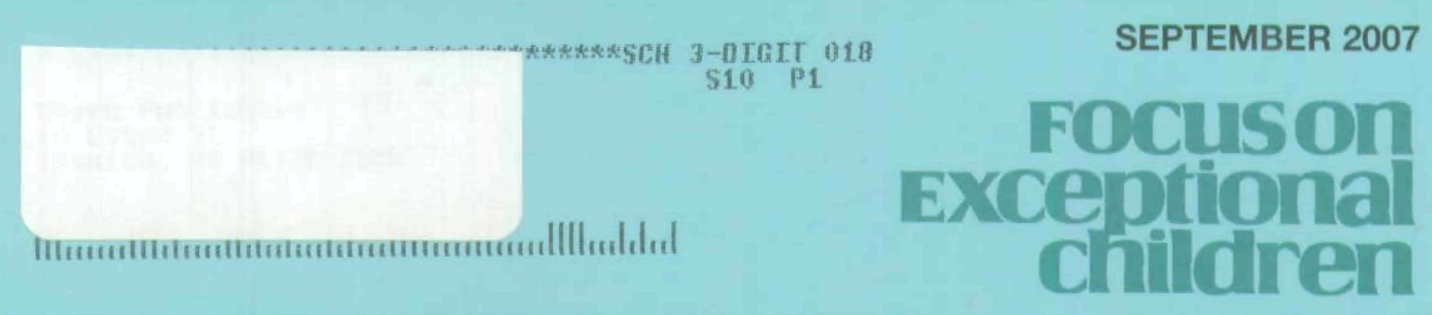

Virginia State Department of Criminal Justice Services. (2001). Second annual evaluation of DCJS funded school resource officer programs. Vossekuil, B., Fin, R.A., Ready, M., Borum, R., \& Modzeleski, W. (2002). The final report and findings of the Safe School Initiative: Implications
for the prevention of school attacks in the United States. Washington, DC: U.S. Secret Service and U.S. Department of Education. Wagner, M. (1995). Outcomes for youth with serious emotional disturbance
in secondary school and early adulthood. Future of Children, 5(2), Wagner, M., Cameto, R., \& Newman, L. (2003). Youth with disabilities: A changing population. A report of findings from the National Longitu-
dial Transition Study (NLTS) and the National Longitudinal Transion Study-2 (NLTS2). Menlo Park, CA: SRI International.

Wagner, M., Marder, C., Blackorby, J., \& Cardoso, D. (2002). The children we serve: The demographic characteristics of elementary and middle
school students with disabilities and their households. Menlo Park, CA: SRI International.
Walker, H. M., Ramsey, E.,

in school: Evidence-based Wadsworth/Thomson Learning.
Walker. H. M., \& Sprague, J. R. quincy, and violence: Causal factors and some potential solutions.
Intervention in School and Clinic, 35(2), 67-73.
Warn, M. J. (1994). Public perceptions and reactions to violent offending and victimization. In A. J. Reiss \& J. A. Roth (Eds.), Understanding Washington, DC: National Academy Press.
Wilson, D.B., Gottfredson, D.C., \& Najaka, S. S. (2001). School-based perevention of problem behaviors: A meta-analysis. Journal of Quantita-
five Criminology, 17. 247-272.

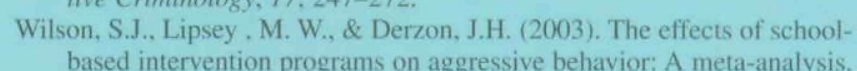
Journal of Consulting \& Clinical Psychology, 71, 136-149. Wilson-Brewer, R., \& Spivak, H. (1994). Violence prevention in schools and other community settings: The pediatrician as initiator, educator,
collaborator, and advocate. Pediatrics, 94(4), 623-630.
Woodruff, D. W. Other. D. Hoffman, C.C. Grunter. A King M. Snow, Woodruff, D.W.., Other, D., Hoffman, C.C., Grunter, A., King, M.A., Snow,
S.T., \& McIntire, J.C. (1999). The role of education in a system of care: Effectively serving children with emotional or behavioral distr-
derv. Systems of care: Promising practices in children's mental health
(1998 Series, Vol. 3). Washington, DC: American Institutes for Research, Center for Effective Collaboration and Practice.
Yell, M.L. (2006). The law and special education. Columbus, OH: Merrill. Zweifler, R., \& DeBeers, J. (2002). The children left behind: How zero folRace and Law, 8(1), 191-220.
Rance impacts our most vul
PERMISSIONS AND COPYRIGHT

All rights are reserved. No part of this publication may be reproduced, photocopied, faxed, stored in a retrieval system, or transmitted in any form or by any means, electronic, mechanical, recording or otherwise. without the prior written permission of the publisher.
Back issues are available for sale. Reproduction requires permission and payment of fees. It is illegal this publication without permission. Direct all inquiries to the permissions editor. 
Copyright of Focus on Exceptional Children is the property of Love Publishing Company and its content may not be copied or emailed to multiple sites or posted to a listserv without the copyright holder's express written permission. However, users may print, download, or email articles for individual use. 